\title{
Geogenic and atmospheric sources for volatile organic compounds in fumarolic emissions from Mt. Etna and Vulcano Island (Sicily, Italy)
}

\author{
F. Tassi, ${ }^{1,2}$ F. Capecchiacci, ${ }^{1,2}$ J. Cabassi, ${ }^{1}$ S. Calabrese, ${ }^{3}$ O. Vaselli, ${ }^{1,2}$ D. Rouwet, ${ }^{4}$ \\ G. Pecoraino, ${ }^{4}$ and G. Chiodini ${ }^{5}$
}

Received 16 February 2012; revised 4 July 2012; accepted 20 July 2012; published 13 September 2012.

[1] In this paper, fluid source(s) and processes controlling the chemical composition of volatile organic compounds (VOCs) in gas discharges from Mt. Etna and Vulcano Island (Sicily, Italy) were investigated. The main composition of the Etnean and Volcano gas emissions is produced by mixing, to various degrees, of magmatic and hydrothermal components. VOCs are dominated by alkanes, alkenes and aromatics, with minor, though significant, concentrations of $\mathrm{O}-, \mathrm{S}$ - and $\mathrm{Cl}(\mathrm{F})$-substituted compounds. The main mechanism for the production of alkanes is likely related to pyrolysis of organic-matterbearing sediments that interact with the ascending magmatic fluids. Alkanes are then converted to alkene and aromatic compounds via catalytic reactions (dehydrogenation and dehydroaromatization, respectively). Nevertheless, an abiogenic origin for the light hydrocarbons cannot be ruled out. Oxidative processes of hydrocarbons at relatively high temperatures and oxidizing conditions, typical of these volcanic-hydrothermal fluids, may explain the production of alcohols, esters, aldehydes, as well as $\mathrm{O}$ - and S-bearing heterocycles. By comparing the concentrations of hydrochlorofluorocarbons (HCFCs) in the fumarolic discharges with respect to those of background air, it is possible to highlight that they have a geogenic origin likely due to halogenation of both methane and alkenes. Finally, chlorofluorocarbon (CFC) abundances appear to be consistent with background air, although the strong air contamination that affects the Mt. Etna fumaroles may mask a possible geogenic contribution for these compounds. On the other hand, no CFCs were detected in the Vulcano gases, which are characterized by low air contribution. Nevertheless, a geogenic source for these compounds cannot be excluded on the basis of the present data.

Citation: Tassi, F., F. Capecchiacci, J. Cabassi, S. Calabrese, O. Vaselli, D. Rouwet, G. Pecoraino, and G. Chiodini (2012), Geogenic and atmospheric sources for volatile organic compounds in fumarolic emissions from Mt. Etna and Vulcano Island (Sicily, Italy), J. Geophys. Res., 117, D17305, doi:10.1029/2012JD017642.

\section{Introduction}

[2] A large number of studies have highlighted the existence of light hydrocarbons $\left(\mathrm{C}_{1}-\mathrm{C}_{10}\right)$, mainly pertaining to the alkane, alkene and aromatic groups, in fluids discharged from volcanic-hydrothermal systems [Des Marais et al.,

\footnotetext{
${ }^{1}$ Department of Earth Sciences, University of Florence, Florence, Italy. ${ }^{2}$ Institute of Geosciences and Earth Resources of the National Research Council (CNR-IGG), Florence, Italy.

${ }^{3}$ Department of Earth and Ocean Sciences (DiSTeM), University of Palermo, Palermo, Italy.

${ }^{4}$ Istituto Nazionale di Geofisica e Vulcanologia, Palermo, Italy.

${ }^{5}$ Osservatorio Vesuviano, Istituto Nazionale di Geofisica e Vulcanologia, Naples, Italy.

Corresponding author: F. Tassi, Department of Earth Sciences, University of Florence, Via La Pira 4, 50121 Florence, Italy. (franco.tassi@unifi.it)

C2012. American Geophysical Union. All Rights Reserved. 0148-0227/12/2012JD017642
}

1981; Welhan and Lupton, 1987; Porshnev and Bondarev, 1989; Giggenbach et al., 1990; Mangani et al., 1991; Giggenbach and Corrales-Soto, 1992; Kiyosu et al., 1992; Capaccioni et al., 1993, 1995, 2001, 2004; Seewald, 1994; Sugisaki and Nagamine, 1995; Darling, 1998; Capaccioni and Mangani, 2001; Burnett et al., 2003; Taran and Giggenbach, 2003; Fiebig et al., 2009; Tassi et al., 2007, 2009a, 2009b, 2010a, 2010b]. Global methane emissions from volcanoes and other natural and anthropogenic sources estimated by Etiope et al. [2008] were used to calculate those of other alkanes, such as ethane and propane [Etiope and Ciccioli, 2009], which resulted up to $6 \mathrm{Tg}$ year $^{-1}$, i.e., significantly lower than the emission fluxes $\left(\sim 16 \mathrm{Tg}\right.$ year $\left.{ }^{-1}\right)$ required to explain the present atmospheric amounts of these gas species [Rudolph, 1995]. Thermogenic decomposition of pre-existing organic matter is widely accepted as the main genetic mechanism for volatile organic compounds (VOCs) in volcanic environments [Des Marais et al., 1981, 1988; Capaccioni et al., 1993, 1995]. Nevertheless, abiogenic 
hydrocarbon formation was also proposed to occur in natural systems [e.g., Abrajano et al., 1988; Szatmari, 1989; Sugisaki and Mimura, 1994; Giggenbach, 1997; Sherwood Lollar et al., 2002; Taran et al., 2002; Taran and Cienfuegos, 2008; Etiope et al., 2011]. Among VOCs, the origin and behavior of halogenated species in volcanic environment is of great interest due to their strong environmental impact and health effects related to i) the key role they play as primary agents of tropospheric and stratospheric ozone depletion [Cicerone et al., 1974; Molina and Rowland, 1974; Farman et al., 1985; Rowland and Molina, 1994; Brune, 1996] and ii) their contribution to global warming [Intergovernmental Panel on Climate Change, 2001; Harnisch and Hoehne, 2002; Harnisch et al., 2002]. The occurrence of halocarbons in volcanic plumes [Cadle et al., 1979; Inn et al., 1981; Leifer et al., 1981; Cronn and Nutmagul, 1982a, 1982b; Brasseur and Granier, 1992] and gas emissions related to magmatic-hydrothermal reservoirs [Stoiber et al., 1971; Isidorov and Zenkevich, 1985; Isidorov et al., 1990, 1992; Gaffney, 1995; Wahrenberger et al., 1998, 2002; Jordan et al., 2000; Jordan, 2003; Schwandner et al., 2004; Frische et al., 2006] have been extensively studied.

[3] Halocarbons are naturally produced from biogenic activity in soils, from biomass combustion and from oceans [Lovelock, 1975; Andreae, 1996; Laturnus et al., 1998; Keene et al., 1999; Khalil et al., 1999; Lobert et al., 1999; Rudolph et al., 2000; Gribble, 2010]. Halocarbons in soils and sediments can abiotically be produced during the oxidation of organic matter caused by reduction of redox pairs, such as $\mathrm{Fe}^{3+}$ and $\mathrm{Fe}^{2+}$ [Keppler et al., 2000, 2002], and through Fenton-like reactions on humic substances [Huber et al., 2009]. However, the recent increase of halocarbon concentrations in air, especially that of chlorofluorocarbons (CFCs), is commonly ascribed to anthropogenic activities [Gamlen et al., 1986; Butler et al., 1999; McCulloch et al., 2003]. In most cases, volcanic halocarbons were interpreted as related to an atmospheric source [Stoiber et al., 1971; Rasmussen and Rasmussen, 1980; Inn et al., 1981; Rasmussen et al., 1981; Pereira et al., 1982; Fink, 1983; Brasseur and Granier, 1992; Gaffney, 1995; Jordan et al., 2000; Jordan, 2003; Frische et al., 2006]. However, Schwandner et al. [2004] reported geochemical evidence supporting the idea of a natural volcanogenic source for halocarbons measured in the soil of La Fossa cone at Vulcano Island (Italy).

[4] The debate on the origin of halocarbons and, in general, of VOCs in volcanic emissions is complicated by the fact that the proposed hypotheses are based on different data sets that can be compared only with difficulty, as a result of adopting different sampling and analytical approaches.

[5] In this paper, VOC geochemistry in volcanic fluids discharged from Mt. Etna and Vulcano Island (Southern Italy) was investigated by GC-MS (Gas chromatographyMass spectrometry) on samples collected using solid traps (ST) [Tassi et al., 2012]. A major aim of this study was to elucidate the possible source(s) and processes controlling VOCs emitted from these volcanoes, emphasizing the genetic aspects of halocarbons. Measured concentrations of halocarbons in gas discharges from these two volcanic systems were compared to those expected considering the fraction of air present in our gas samples, calculated on the basis of their Ar concentrations. Such a detailed evaluation of halocarbon contribution due to background air, which represents the main novelty of the present paper, is of fundamental importance to assess if these gas compounds, commonly ascribed to anthropogenic activity, may have a geogenic source in volcanic fluids.

\section{Volcanological Background}

\subsection{Mt. Etna}

[6] Mt. Etna (eastern Sicily) is a strato-volcano built on a lower tholeitic shield unit [Chester et al., 1985; Tanguy et al., 1997] and located at the collision boundary of the African and European blocks [Barberi et al., 1974]. The activity of this volcano, which is the largest in continental Europe $\left(\sim 1,200 \mathrm{~km}^{2}\right.$ of total surface with a maximum height of $3,300 \mathrm{~m}$ a.s.1.), is controlled by the intersection of NNW- and NNE-trending fault systems. The actual thickness of the Etnean volcanic products, emplaced over the sedimentary basement, is about 2,000 m [Ogniben, 1966]. Mt. Etna is one of the most active volcanoes in the world, being characterized by frequent eruptions and a persistent carbon dioxide $\left(\mathrm{CO}_{2}\right)$ rich plume, whose total emission was estimated to correspond to $10 \%$ of the global emission of volcanic $\mathrm{CO}_{2}$ [Gerlach, 1991]. The frequent eruptive activity [Allard et al. 2006] heavily affects the morphology of the summit area [Neri and Acocella, 2006; Neri et al., 2008], which presently consists of a central crater (Voragine) surrounded by three active cones (Bocca Nuova, NE Crater, and SE Crater; Figure 1), and is cut by N-S oriented fracture systems, mainly related to by extensional stress produced by magma ascent [Neri et al., 2004]. Mt. Etna lies in an anorogenic zone and it is characterized by OIB-type magmas with geochemical and isotopic features similar to those of arc-related volcanoes [Schiano et al., 2001; Tonarini et al., 2001]. According to Liotta et al. [2010], fluids released from the magmatic system are discharged into the atmosphere from both the summit craters and the fumaroles located at the crater rims. Severe air contamination due to the high permeability of the feeding fractures and modest fluid contribution from a peripheral hydrothermal reservoir heavily mask the magmatic component of the gas emissions.

\subsection{Vulcano Island}

[7] Vulcano is the southernmost island of the Aeolian Archipelago (Sicily, southern Italy), a volcanic arc generated by subduction beneath the Tyrrhenian Sea [Barberi et al., 1974; Beccaluva et al., 1985]. Since the last eruption in 1888-1890 [Mercalli, 1891; Keller, 1980], Vulcano has experienced intense fumarolic activity, mainly from the La Fossa cone. Two main periods of volcanic unrest, marked by a strong increase of fumarolic activity, affected this volcano, in 1913-1923 [Sicardi, 1940] and in 1977-1993 [Martini, 1993; Chiodini et al., 1995], when temperatures up to $600^{\circ}$ and $690^{\circ} \mathrm{C}$, respectively, were measured at the crater fumaroles. In 2004-2005, an anomalous seismic activity, as well as significant changes of both the composition of the crater fumaroles and the diffuse $\mathrm{CO}_{2}$ degassing from the flanks of La Fossa cone were measured, providing evidence of a third volcanic unrest [Granieri et al., 2006]. These crises were interpreted as related to episodes of fluid transfer from stationary magma bodies, since no geophysical evidence of magma migration was detected [Barberi et al., 1991; 


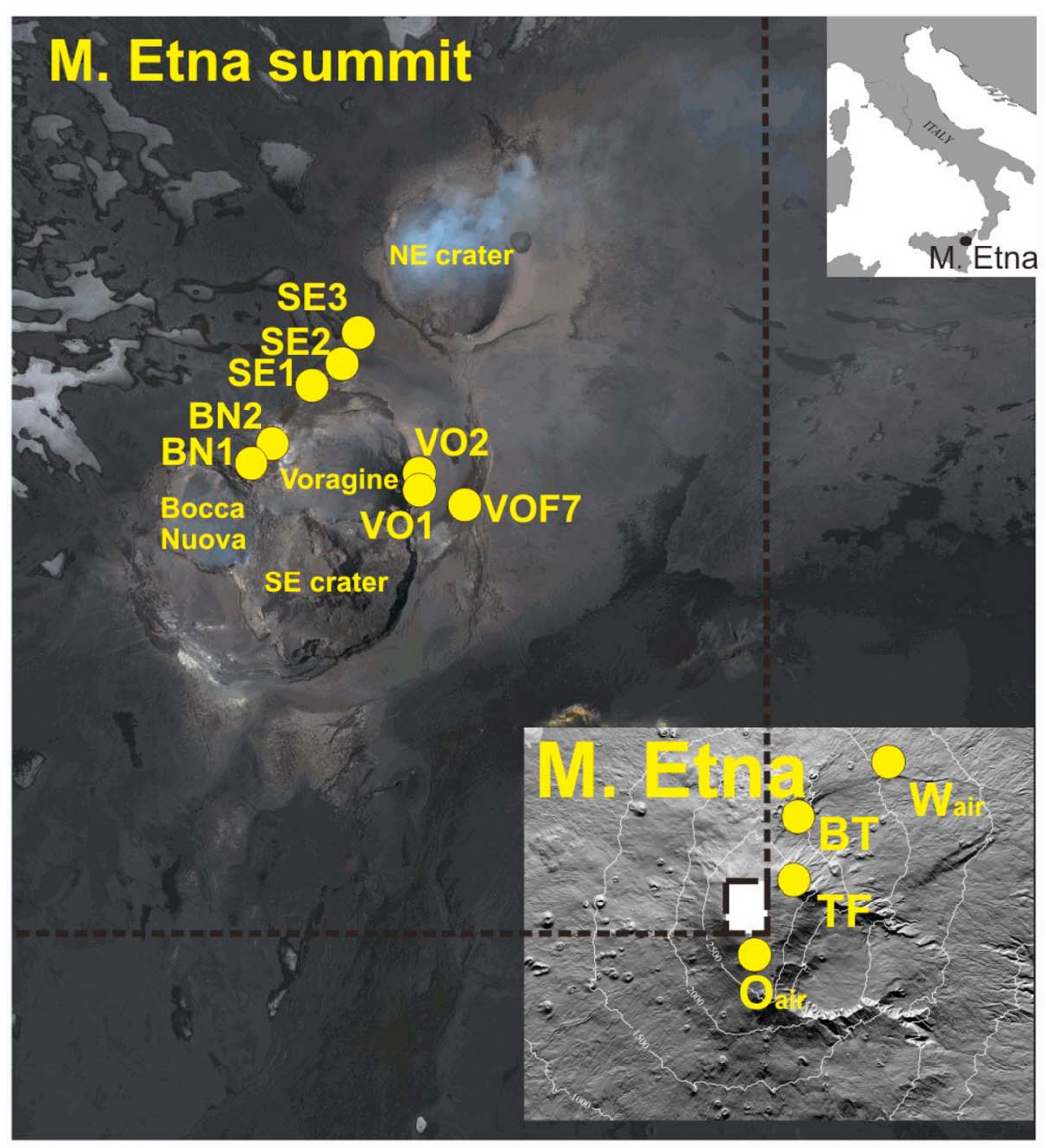

Figure 1. Geographic map of Mt. Etna summit craters showing locations of the sampled gas discharges.

Chiodini et al., 1992; Bonaccorso, 2002; Granieri et al., 2006]. Several geochemical conceptual models were proposed to describe the fluid circulation system feeding the gas discharges of Vulcano Island [Carapezza et al., 1981; Cioni and D'Amore, 1984; Panichi and Noto, 1992; Bolognesi and D'Amore, 1993; Chiodini et al., 1993, 1995, 2000; Martini, 1996; Capasso et al., 1997]. It is generally accepted that the chemical composition of fumarolic fluids is characterized by the presence of magmatic and hydrothermal components, the latter showing significant seawater contribution, that mix at different degrees. The current exhalative activity mainly occurs in the northern sector of La Fossa crater, where outlet temperatures of the fumarolic vents are $<400^{\circ} \mathrm{C}$, and from boiling and bubbling pools located in the Levante beach (Figure 2).

\section{Sampling and Analytical Methods}

\subsection{Sampling Method}

[8] At Mt. Etna, gas samples were collected from fumaroles located i) along the rims of Voragine (VOF7, VO1, VO2, SE1, SE2 and SE3 samples) and Bocca Nuova (BN1 and BN2 samples) craters $(\sim 3,300 \mathrm{~m}$ a.s.l.), ii) at Torre del Filosofo (TF sample), a touristic site in the SE sector of the summit area $(\sim 2,750 \mathrm{~m}$ a.s.l. $)$, and iii) at the Bottoniera craters (BT sample) in the NW flank of the volcano $(\sim 2,500 \mathrm{~m}$ a.s.1.), which opened during the 2002/2003 eruption (Figure 1). Two air samples were collected from distal sites located few $\mathrm{km} \mathrm{NW}$ of the NE crater $\left(\mathrm{O}_{\text {air }}\right)$ and at Bosco Ragabo $\left(\mathrm{W}_{\text {air }}\right.$ ) (Figure 1).

[9] At Vulcano Island gas samples were collected from fumarolic gas discharges positioned in the northern sector of La Fossa cone (FNB and FZ samples) and from bubbling gas exhalations in the Levante beach (FM and IS samples), near the village of Vulcano (Figure 2). Two air samples were collected from the proximity of Vulcano village $\left(\mathrm{V}_{\text {air }}\right)$ and from La Fossa crater rim $\left(\mathrm{C}_{\mathrm{air}}\right)$, respectively.

[10] Gas sampling for the determination of the inorganic gas species, $\mathrm{CH}_{4}$ and $\mathrm{C}_{1}-\mathrm{C}_{4}$ alkanes and alkenes was carried out using pre-evacuated $60 \mathrm{~mL}$ glass flasks equipped with a Thorion ${ }^{\circledR}$ valve and filled with $20 \mathrm{~mL}$ of a $4 \mathrm{M} \mathrm{NaOH}$ and $0.15 \mathrm{M} \mathrm{Cd}(\mathrm{OH})_{2}$ suspension to trap soluble and acidic gas species in the liquid phase and separate $\mathrm{SO}_{2}$ (dissolved in the liquid phase) and $\mathrm{H}_{2} \mathrm{~S}$ (precipitating as $\mathrm{CdS}$ ) to prevent any reaction in the gas phase [Montegrossi et al., 2001]. Fumarolic gas was conveyed into the sampling flask using a $0.7 \mathrm{~m}$ long titanium tube, inserted as deeply as possible into the vent and connected to a sampling line constituted by dewared glass tubes, whereas bubbling gases were collected using a funnel positioned up-side-down above the emission (Figure 3) [Montegrossi et al., 2001; Vaselli et al., 2006]. The analysis of VOCs, excluding those species analyzed in the sampling flask head-space, was carried out on samples collected in solid traps (ST) consisting of stainless steel tubes 


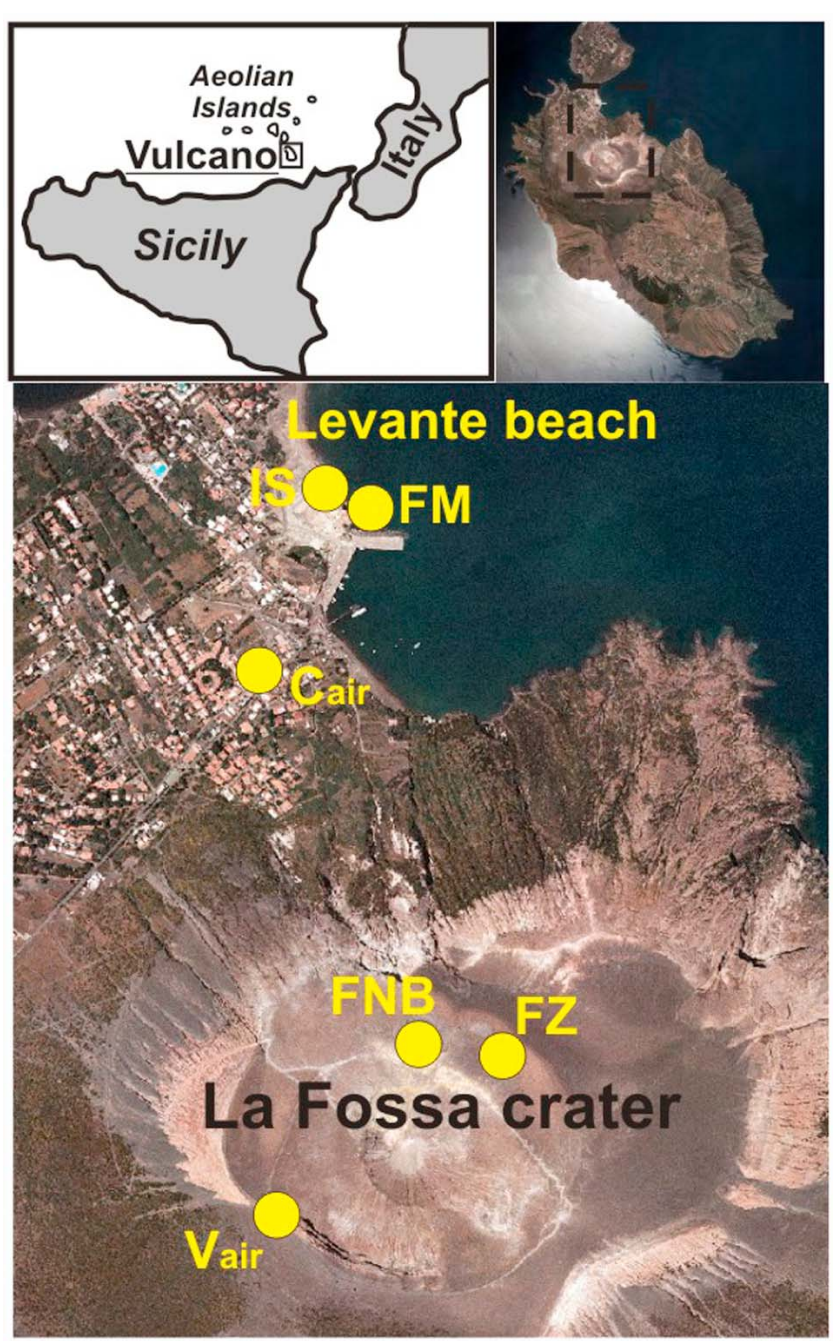

Figure 2. Geographic map of Vulcano Island showing locations of the sampled gas discharges.

packed with three adsorbent beds (Carbosieve 111, Carboxen B and Carboxen C; Supelco Inc., USA). Solid traps were preferred to SPME (Solid Phase Micro Extraction) fibers having a three-phase adsorbent assembly (divinylbenzeneCarboxen-polydimethylsiloxane) similar to that of the ST [Shirey, 1999], as a large quantity of sample can be stored in the ST, allowing the detection of compounds at very low concentrations, i.e., ten of parts per trillion by volume (pptv), such as the halocarbons [Tassi et al., 2012].

[11] Gases were conveyed to the ST using a sampling line consisting of the above described dewared glass tubes (or, alternatively, the funnel) at which an ice-cooled condenser (Graham type condenser) was connected (Figure 3). The gas flux through the ST was regulated at $200 \mathrm{~mL} / \mathrm{min}$ by a lowflux portable pump. At each sampling site (fumarolic vent and air samples) gases were flushed through the ST for $4 \mathrm{~h}$, corresponding to $\sim 60 \mathrm{~L}$ of sample. The condenser prevented the entrance into the ST of water vapor and the highly soluble gas species $\left(\mathrm{SO}_{2}, \mathrm{HCl}, \mathrm{HF}\right.$ and $\left.\mathrm{H}_{2} \mathrm{~S}\right)$, typically present at Vulcano and Mt. Etna fumaroles [Chiodini et al., 1995; Liotta et al., 2010]. This method minimizes the deleterious effects of these compounds on the ST and the hydrolysis of adsorbed VOCs [Tassi et al., 2012]. Sampled STs were kept at low temperature $\left(<10^{\circ} \mathrm{C}\right)$ to avoid thermal degradation of VOCs.

\subsection{Analysis of the Inorganic Compounds and $\mathrm{C}_{1}-\mathrm{C}_{4}$ Hydrocarbons}

[12] The inorganic compounds stored in the sampling flask head-space, i.e., $\mathrm{N}_{2}, \mathrm{O}_{2}, \mathrm{Ar}, \mathrm{H}_{2}, \mathrm{He}$ and carbon monoxide (CO), were analyzed by a Shimadzu $15 \mathrm{~A}$ gas-chromatograph equipped with a thermal conductivity detector (TCD), using a $10 \mathrm{~m}$ long stainless steel packed molecular sieve column and helium or argon (the latter being used for $\mathrm{He}$ and $\mathrm{Ne}$ analysis) as carrier gas. $\mathrm{C}_{1}-\mathrm{C}_{4}$ hydrocarbons were analyzed by a Shimadzu 14a gas-chromatograph equipped with a flame ionization detector (FID), using a $10 \mathrm{~m}$ long stainless steel column $(\phi=2 \mathrm{~mm})$ packed with Chromosorb PAW 80/100 mesh coated with $23 \%$ SP 1700 , and helium as carrier gas [Vaselli et al., 2006]. The caustic solution was separated from solid $\mathrm{CdS}$ by centrifugation, oxidized with $\mathrm{H}_{2} \mathrm{O}_{2}$, and used for the analysis of: 1) $\mathrm{CO}_{2}$ as $\mathrm{CO}_{3}^{2-}$ by automatic titration with $0.1 \mathrm{~N} \mathrm{HCl}$; 2) $\mathrm{HF}, \mathrm{HCl}$ and $\mathrm{SO}_{2}$ as $\mathrm{F}^{-}, \mathrm{Cl}^{-}$and $\mathrm{SO}_{4}^{2-}$, respectively, by ion chromatography (Metrohm 761). Solid $\mathrm{CdS}$ was dissolved with $\mathrm{H}_{2} \mathrm{O}_{2}$, to analyze $\mathrm{H}_{2} \mathrm{~S}$ as $\mathrm{SO}_{4}^{2-}$ in a separate ion chromatography run. Water vapor was estimated by the difference (in weight) between the collected gas ( $\mathrm{W}=$ $\mathrm{W}_{\mathrm{as}}-\mathrm{W}_{\mathrm{bs}}$, where $\mathrm{W}_{\mathrm{as}}$ is the weight of the flask after sampling and $\mathrm{W}_{\mathrm{bs}}$ is the weight of the flask before sampling) and the sum of the analyzed species [Montegrossi et al., 2001; Vaselli et al., 2006]. Quantitative analyses of the inorganic compounds and $\mathrm{C}_{1}-\mathrm{C}_{4}$ hydrocarbons stored in the flask headspace were carried out using an external standard calibration procedure based on analysis of standard gas mixtures provided and certified by Supelco Analytical. The analytical error was $<5 \%$.

\subsection{Analysis of VOCs}

[13] Conditioning of the ST was carried out at $250^{\circ} \mathrm{C}$ for 20 min under a stream of purified helium using a DANI Master thermal desorber (TD). VOCs trapped in the ST were desorbed at $250^{\circ} \mathrm{C}$ for 20 min using the $\mathrm{TD}$, which was equipped with a focusing quartz trap having a three-phase absorbent assembly similar to that of the ST. The focusing trap absorbed the VOCs released from the ST at $-5^{\circ} \mathrm{C}$ and then they were thermally desorbed them at $220^{\circ} \mathrm{C}$ for $2 \mathrm{~min}$. VOCs released from the focusing trap were transferred through a transfer line maintained at $220^{\circ} \mathrm{C}$ to the injection port, operating in splitless mode, of a Thermo Trace GC Ultra gas chromatograph coupled with a Thermo DSQ Quadrupole Mass Spectrometer (GC-MS). Chromatographic separation was achieved using a $30 \mathrm{~m} \times 0.25 \mathrm{~mm}$ i.d. $0.25 \mu \mathrm{m}$ film thickness TR-5 fused silica capillary column (Thermo). The carrier gas was helium set to a flow rate of $0.8 \mathrm{~mL} / \mathrm{min}$ in constant pressure mode. The column oven temperature program was as follows: $25^{\circ} \mathrm{C}$ (hold $10 \mathrm{~min}$ ), ramp at $4.5^{\circ} \mathrm{C} / \mathrm{min}$ to $140^{\circ} \mathrm{C}$ (hold $3 \mathrm{~min}$ ), ramp at $20^{\circ} \mathrm{C} / \mathrm{min}$ up to $230^{\circ} \mathrm{C}$ (hold $6 \mathrm{~min})$. The quadrupole mass spectrometer operated in positive electron impact mode (EI) with an ionization energy of $70 \mathrm{eV}$ and a source temperature of $250^{\circ} \mathrm{C}$. The detector was set in full scan mode, at a scan rate of 1 scan per second, in the mass range 25-400 a.m.u. (atomic mass unit). The temperature of the GC-to-MS transfer line was set at $250^{\circ} \mathrm{C}$. 


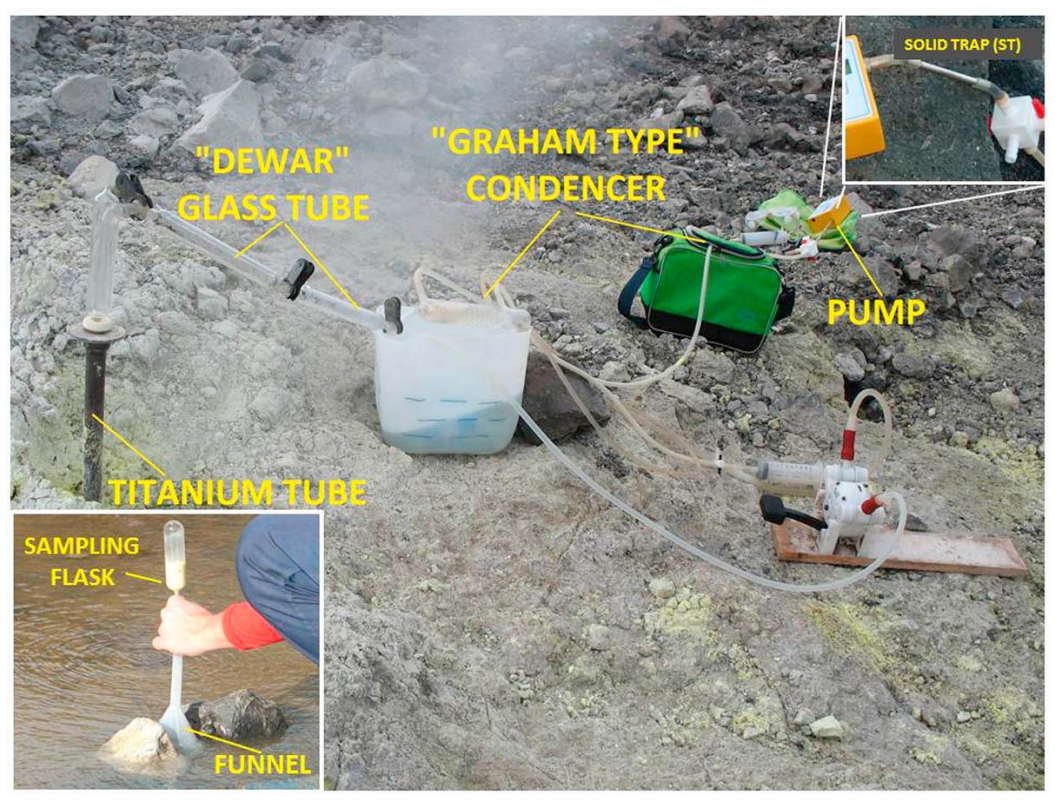

Figure 3. Equipment for the gas sampling from fumaroles and bubbling pools, which was used for analysis of the main gases and volatile organic compounds (VOCs).

[14] Each VOC detected by the quadrupole detector was identified according to both the retention time of the chromatographic peak and the mass spectra of the molecule fragments. Library mass spectra (obtained from http://www. nist.gov/srd/nistla.htm) were used for comparison.

[15] Quantitative analyses were carried out using an external standard calibration procedure based on calibration curves constructed measuring the instrumental signal of Accustandard $\mathbb{R}$ standard mixtures charged into the same type of ST used during the fumarole sampling. To determine the molar concentrations of the VOCs, 6 different standard mixtures were used: 1$)$ alkanes $\left(\mathrm{C}_{5}-\mathrm{C}_{8}\right.$ alkanes, at concentrations ranging from 5 to $50 \mathrm{ppb}), 2$ ) alkenes $\left(\mathrm{C}_{5}-\mathrm{C}_{9}\right.$ alkenes, at concentrations ranging from 5 to $50 \mathrm{ppb}), 3$ ) aromatic compounds ( 15 species at concentrations ranging from 50 to $500 \mathrm{ppb}$ ), 4) S-bearing compounds (6 species at $20 \mathrm{ppb})$, 5) O-bearing compounds (15 species at concentrations ranging from 5 to $50 \mathrm{ppb}$ ), and 6) halogenated compounds ( 15 species at concentrations ranging from 0.05 to $5 \mathrm{ppb}$ ). The recovery values of the ST were determined on the basis of separate direct injection of the standard mixtures carried out using a volumetric gas syringe. The values of the relative standard deviation (RSD), calculated from five replicate analyses of the standard mixtures, were $<5 \%$. The limit of quantification (LOQ) was determined by linear extrapolation from the lowest standard in the calibration curve using the area of a peak having a signal/noise ratio of 5 [Mangani et al., 2003; Tassi et al., 2012]. Possible loss of VOCs by dissolution in the condensate was tested by analyzing the separated liquid phase of the Vulcano samples by GC-MS coupled with a Tekmar Stratum Purge and Trap (PT) instrument. VOCs were displaced from the condensate $(5 \mathrm{~mL})$, by bubbling helium for $11 \mathrm{~min}$ at a flow rate of $40 \mathrm{~mL} / \mathrm{min}$ at ambient temperature, and transferred to a focusing trap having the same three-phase absorbent assembly of the TD. The released VOCs were absorbed by the PT focusing trap at $-5^{\circ} \mathrm{C}$ and then thermally desorbed at $220^{\circ} \mathrm{C}$ for 2 min and transferred to the GC-MS injection port.

\section{Analytical Results}

\subsection{Main Gas Compounds}

[16] Outlet temperatures (in ${ }^{\circ} \mathrm{C}$ ), concentrations of the inorganic gases $\left(\mathrm{CO}_{2}, \mathrm{HCl}, \mathrm{HF}, \mathrm{SO}_{2}, \mathrm{H}_{2} \mathrm{~S}, \mathrm{~N}_{2}, \mathrm{Ar}, \mathrm{O}_{2}, \mathrm{H}_{2}\right.$, $\mathrm{He}$ and $\mathrm{CO}$ ) and $\mathrm{CH}_{4}$, (expressed in $\mathrm{mmol} / \mathrm{mol}$ ) in the dry gas fraction, steam concentrations (expressed in \% by vol.) and percentages of air fraction $\left(\mathrm{A}_{\mathrm{f}}\right)$ of Mt. Etna and Vulcano gas discharges are reported in Table 1.

[17] The outlet temperatures of the Etnean fumaroles range from $75^{\circ}$ to $337^{\circ} \mathrm{C}$, while those of the Vulcano fumaroles (FNB and FZ) are from $355^{\circ}$ to $99^{\circ} \mathrm{C}$, respectively. The gases of the Levante beach at Vulcano Island, namely FM and IS, are bubbling in meteoric and seawater at $<20^{\circ}$ and $80^{\circ} \mathrm{C}$, respectively. The gas composition of the Etnean fumaroles is dominated by water vapor ( $>76 \%$ by vol.), whereas the dry gas phase mainly consists in comparable amounts of $\mathrm{CO}_{2}$ (up to $697 \mathrm{mmol} / \mathrm{mol}$ ), and $\mathrm{N}_{2}$ (up to $525 \mathrm{mmol} / \mathrm{mol}$ ), with the only exception of that of the VOF7 sample, being dominated by $\mathrm{CO}_{2}(955 \mathrm{mmol} / \mathrm{mol})$ and showing relatively low $\mathrm{N}_{2}$ concentrations $(20 \mathrm{mmol} / \mathrm{mol})$. The Etnean $\mathrm{N}_{2}$-rich fumaroles are characterized by: 1) relatively high $\mathrm{O}_{2}$ (up to $62.9 \mathrm{mmol} / \mathrm{mol}$ ) and $\mathrm{Ar}$ (up to $5.8 \mathrm{mmol} / \mathrm{mol}$ ) concentrations, indicating a strong air contamination; 2) $\mathrm{H}_{2}$ concentrations ranging from 0.81 to $4.17 \mathrm{mmol} / \mathrm{mol}$; 3) significant contents of $\mathrm{SO}_{2}, \mathrm{HCl}$ and $\mathrm{HF}$ (up to $6.51,2.35$ and $0.41 \mathrm{mmol} / \mathrm{mol}$, respectively); 4) relatively low $\mathrm{H}_{2} \mathrm{~S}(<0.62 \mathrm{mmol} / \mathrm{mol})$, $\mathrm{CO}(<0.0087 \mathrm{mmol} / \mathrm{mol})$ and $\mathrm{CH}_{4}(<0.0081 \mathrm{mmol} / \mathrm{mol})$ concentrations. The VOF7 fumarole has the highest $\mathrm{SO}_{2}$ $(15.3 \mathrm{mmol} / \mathrm{mol})$ and $\mathrm{H}_{2} \mathrm{~S}(8.45 \mathrm{mmol} / \mathrm{mol})$ concentrations among the Etnean gases and relatively low $\mathrm{HCl}, \mathrm{HF}, \mathrm{H}_{2}$ and CO concentrations $(0.71,0.15,0.011$ and $0.0002 \mathrm{mmol} / \mathrm{mol}$, respectively). The two distal Etnean fumaroles (TF and BT; 
Table 1. Outlet Temperatures, Chemical Composition in the Dry Gas Fraction (in mmol/mol), Steam Concentrations and Air Fraction (Af) of Fumaroles From Mt. Etna and of Fumaroles (FZ and FNB) and Bubbling Gases (FM and IS) From Vulcano Island

\begin{tabular}{|c|c|c|c|c|c|c|c|c|c|c|c|c|c|c|c|c|c|}
\hline Sample & Date & $\begin{array}{c}\mathrm{T} \\
\left({ }^{\circ} \mathrm{C}\right)\end{array}$ & $\mathrm{CO}_{2}$ & $\mathrm{SO}_{2}$ & $\mathrm{HF}$ & $\mathrm{HCl}$ & $\mathrm{H}_{2} \mathrm{~S}$ & $\mathrm{~N}_{2}$ & $\mathrm{CH}_{4}$ & $\mathrm{Ar}$ & $\mathrm{O}_{2}$ & $\mathrm{Ne}$ & $\mathrm{H}_{2}$ & $\mathrm{He}$ & $\mathrm{CO}$ & $\begin{array}{c}\text { Steam } \\
(\%)\end{array}$ & $\begin{array}{l}\mathrm{A}_{\mathrm{f}} \\
(\%)\end{array}$ \\
\hline \multicolumn{18}{|c|}{ Mt. Etna } \\
\hline VOF7 & 20 Jun 2010 & 94 & 955 & 15.3 & 0.15 & 0.71 & 8.45 & 20 & 0.0088 & 0.18 & 0.56 & $<0.001$ & 0.011 & 0.015 & 0.0002 & 81.5 & 1.9 \\
\hline VO1 & 20 Jun 2010 & 321 & 507 & 6.51 & 0.41 & 2.35 & 0.56 & 467 & 0.0025 & 5.2 & 6.65 & 0.0095 & 4.17 & 0.007 & 0.0113 & 76.4 & 55.8 \\
\hline VO2 & 20 Jun 2010 & 337 & 485 & 4.89 & 0.39 & 1.87 & 0.62 & 489 & 0.0024 & 5.6 & 8.78 & 0.0098 & 3.85 & 0.006 & 0.0087 & 78.8 & 60.0 \\
\hline BN1 & $05 \mathrm{Jul} 2011$ & 158 & 697 & 2.31 & 0.26 & 1.15 & 0.29 & 266 & 0.0031 & 2.5 & 28.6 & 0.0044 & 1.56 & 0.006 & 0.0021 & 84.5 & 26.3 \\
\hline BN2 & 05 Jul 2011 & 160 & 680 & 2.44 & 0.24 & 1.21 & 0.25 & 284 & 0.0037 & 2.4 & 26.6 & 0.0043 & 2.74 & 0.004 & 0.0026 & 88.6 & 25.7 \\
\hline SE1 & $05 \mathrm{Jul} 2011$ & 87 & 534 & 1.55 & 0.06 & 0.26 & 0.15 & 411 & 0.0081 & 4.5 & 47.5 & 0.0083 & 0.81 & 0.004 & $<0.0001$ & 90.1 & 48.2 \\
\hline SE2 & 06 Jul 2011 & 176 & 522 & 2.35 & 0.11 & 0.45 & 0.26 & 432 & 0.0024 & 4.4 & 36.6 & 0.0082 & 1.34 & 0.006 & 0.0015 & 82.2 & 47.5 \\
\hline SE3 & 06 Jul 2011 & 98 & 543 & 1.74 & 0.05 & 0.25 & 0.32 & 387 & 0.012 & 4.1 & 62.9 & 0.0071 & 1.11 & 0.004 & $<0.0001$ & 91.1 & 43.8 \\
\hline $\mathrm{TF}$ & 21 Jun 2010 & 85 & 394 & $<0.01$ & $<0.01$ & $<0.01$ & $<0.01$ & 525 & 0.29 & 5.8 & 75.2 & 0.0096 & $<0.001$ & 0.005 & $<0.0001$ & 92.1 & 62.8 \\
\hline BT & 07 Jul 2011 & 75 & 617 & $<0.01$ & $<0.01$ & $<0.01$ & $<0.01$ & 356 & 12 & 3.1 & 11.9 & 0.0056 & 0.21 & 0.005 & $<0.0001$ & 80.3 & 33.4 \\
\hline \multicolumn{18}{|c|}{ Vulcano Island } \\
\hline FZ & Der & 99 & 97 & 9.9 & 0.1 & 0.3 & 11 & 8.11 & 93 & 0.064 & 1 & $<0$. & 0. & 0.011 & & 96.3 & 0.7 \\
\hline FNB & $11 \operatorname{Dec} 2011$ & 355 & 925 & 28.6 & 1.0 & 21.1 & 2 & 16.6 & 0.00041 & 0.079 & 0.098 & $<0.001$ & 2.24 & 0.012 & 0.0036 & 95.4 & 0.8 \\
\hline FM & 11 Dec 2011 & $<20$ & 990 & $<0.01$ & $<0.01$ & $<0.01$ & 0.42 & 7.35 & 1.45 & 0.14 & 0.58 & $<0.001$ & 0.028 & 0.042 & 0.0005 & 0.31 & 1.5 \\
\hline IS & 11 Dec 2011 & 80 & 982 & $<0.01$ & $<0.01$ & $<0.01$ & 2.02 & 12.7 & 3.09 & 0.17 & 0.021 & $<0.001$ & 0.037 & 0.012 & 0.0012 & 7.89 & 1.8 \\
\hline
\end{tabular}

Figure 1) have low $\mathrm{H}_{2}(<0.21 \mathrm{mmol} / \mathrm{mol})$, high $\mathrm{CH}_{4}$ (up to $12 \mathrm{mmol} / \mathrm{mol}$ ), whereas acidic compounds $\left(\mathrm{SO}_{2}, \mathrm{HCl}, \mathrm{HF}\right.$ and $\mathrm{H}_{2} \mathrm{~S}$ ) and $\mathrm{CO}$ are below the instrumental detection limit that is 0.01 (for the acidic gas species) and 0.0001 (for carbon monoxide) $\mathrm{mmol} / \mathrm{mol}$.

[18] The fumaroles of La Fossa crater in Vulcano Island show dominant water vapor (up to $96.3 \%$ by vol.), followed by $\mathrm{CO}_{2}$ (up to $977 \mathrm{mmol} / \mathrm{mol}$ ), acidic gases $\left(\mathrm{SO}_{2}, \mathrm{HCl}, \mathrm{H}_{2} \mathrm{~S}\right.$ and $\mathrm{HF}$ concentrations are up to 28.6, 21.2, 5.22 and 1.05 $\mathrm{mmol} / \mathrm{mol}$, respectively), $\mathrm{N}_{2}$ (up to $16.6 \mathrm{mmol} / \mathrm{mol}$ ) and $\mathrm{H}_{2}$ (up to $2.24 \mathrm{mmol} / \mathrm{mol}$ ). Atmospheric gases $\left(\mathrm{O}_{2}, \mathrm{Ar}\right.$ and $\mathrm{Ne}$ ) $\mathrm{CH}_{4}$ and $\mathrm{CO}$ are $<0.1 \mathrm{mmol} / \mathrm{mol}$. The beach gas exhalations are mainly composed of $\mathrm{CO}_{2}$ (up to $990 \mathrm{mmol} / \mathrm{mol}$ ), $\mathrm{N}_{2}$ (up to $12.7 \mathrm{mmol} / \mathrm{mol}$ ) and $\mathrm{CH}_{4}$ (up to $3.09 \mathrm{mmol} / \mathrm{mol}$ ), whereas water vapor is $<7.89 \%$ by vol., and $\mathrm{SO}_{2}, \mathrm{HCl}$ and $\mathrm{HF}$ are lower than the instrumental detection limit, as these highly soluble species likely dissolve into seawater as they reach the surface. Oxygen and Ar concentrations (up to 0.58 and $0.17 \mathrm{mmol} / \mathrm{mol}$, respectively) are slightly higher than those of the crater fumaroles, whereas $\mathrm{H}_{2}$ and $\mathrm{CO}$ were lower than 0.037 and $0.0012 \mathrm{mmol} / \mathrm{mol}$, respectively. The chemical composition of the main constituents of the gas discharges from both Mt. Etna and Vulcano Island determined for the present work are consistent with those reported for these systems in recent papers [Paonita et al., 2002; Liotta et al., 2010].

\subsection{Volatile Organic Compounds}

[19] Up to 64 different VOCs, pertaining to the alkane (12 compounds), alkene (11 compounds), aromatic (11 compounds), sulfonated (4 compounds), oxygenated (12 compounds), and halogenated (14 compounds) groups, were identified and quantified. VOC concentrations, expressed in ppbv (part per billion by volume), are reported in Table 2 . The sum of VOC concentrations ranges from 193 to $10,625 \mathrm{ppbv}$, and the highest concentration recorded for a single compound (ethane) is 7,500 ppbv (BT sample). In the Vulcano condensates VOCs were below detection limits ( $\sim 0.01 \mathrm{ppbv}$ for all the compounds determined by GC-MS), indicating that the separation of the condensed phase during sampling did not cause significant loss of VOCs in the gas phase. This reflects the low solubility of VOCs in water, which is even less in volcanic condensates characterized by high ionic strength. The pie diagrams in Figure 4 show that the most abundant VOCs of the Etnean fumaroles are alkanes, ranging from $56 \%$ to $87 \%$ of VOCs, followed by aromatic and oxygenated compounds (up to $30 \%$ and $15 \%$, respectively). Alkene and sulfonated compounds are a minor but significant VOC fraction (up to $5.8 \%$ and $6 \%$ ), whereas halocarbons (Table 2) are $<0.5 \%$. Gases from La Fossa crater are dominated by sulfonated and oxygenated compounds (up to $27 \%$ and $57 \%$, respectively), and show relatively high concentrations of alkenes (14\% and $15 \%$ in the $\mathrm{FZ}$ and $\mathrm{FNB}$ gases, respectively), and low concentrations of alkane (3.8\% and $13 \%$ in the FNB and FZ gases, respectively) and aromatic (up to $8.9 \%$ ) compounds (Figures $5 \mathrm{a}$ and $5 \mathrm{~b}$ ). Halocarbons (Table 2) are $<0.6 \%$. The VOC composition of the Vulcano beach gas discharges (Figures $5 \mathrm{c}$ and $5 \mathrm{~d}$ ) is different with respect to that of the crater fumaroles: alkanes are by far the most abundant group (68\% and $74 \%$ in the FM and IS gases, respectively), followed by aromatic compounds (up to $30 \%$ ) and minor concentrations of oxygenated, alkene and sulfonated species (up to $0.7 \%, 0.8 \%$ and $1 \%$, respectively). Halocarbons (Table 2 ) are $0.02 \%$ and $0.05 \%$ in IS and FM, respectively.

[20] Among the $\mathrm{C}_{2}-\mathrm{C}_{8}$ alkanes, ethane has the highest concentrations in all the samples (ranging from 5.2 to 7,500 ppbv). Branched compounds are less abundant than their linear homologues, a common feature in volcanic gases, likely depending on the relatively high stability of $n$-alkanes (linear chain) with respect to $i$-alkanes (branched chain) at increasing temperatures [Astaf'ev et al., 1973; Darling, 1998]. Heavier alkanes $\left(\mathrm{C}_{9}-\mathrm{C}_{12}\right)$ were also detected but not quantified. Linear/branched ratios of alkenes are significantly lower than that of alkanes, mainly depending on the relatively high concentrations of methylpropene and (3)methyl (2)pentene (up to 9.6 and 15 ppbv, respectively). Benzene concentrations (ranging from 3.7 and 1,240 ppbv) are significantly higher (up to three orders of magnitude) than those of its numerous methylated and ethylated derivatives, 


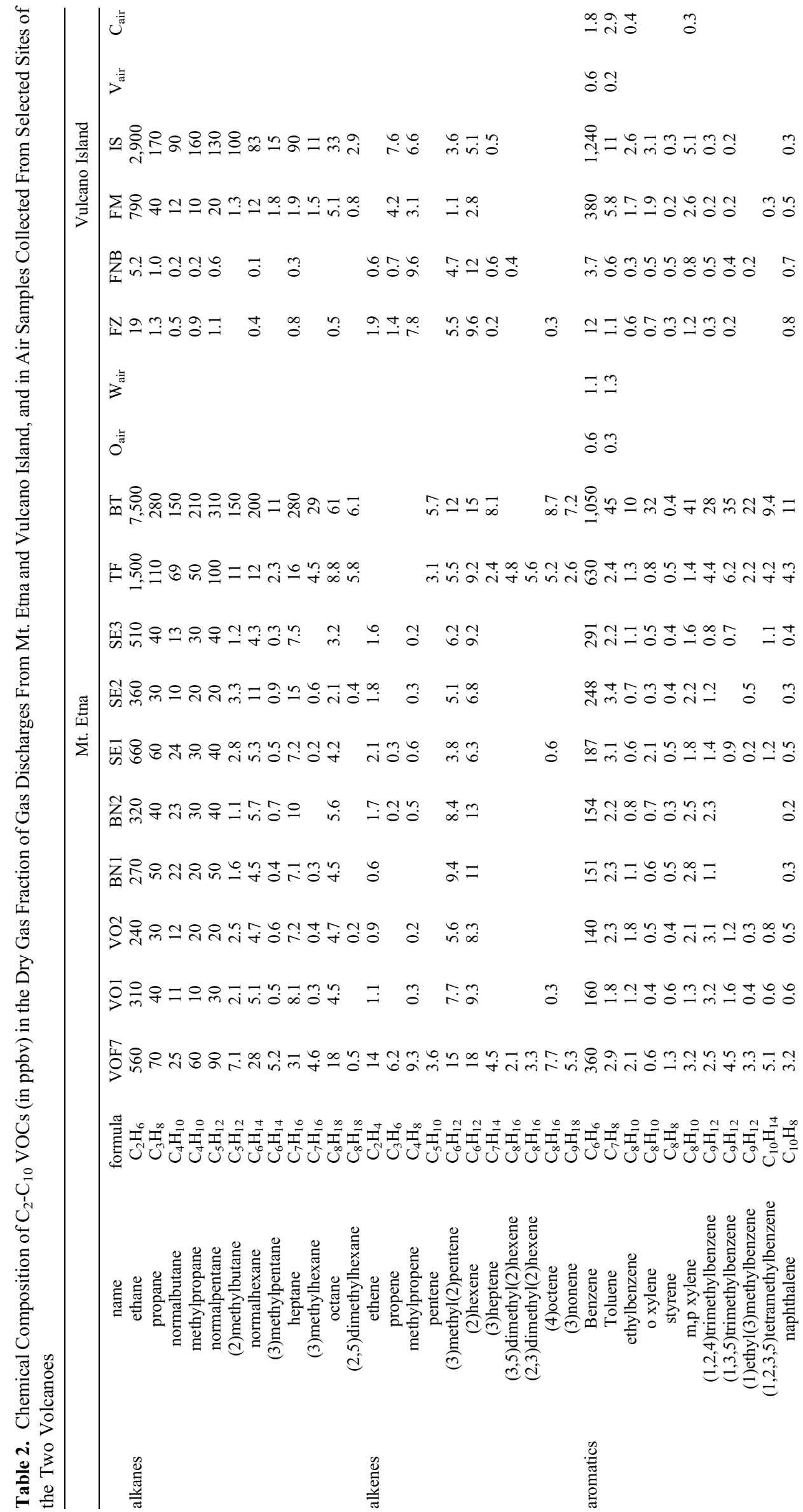




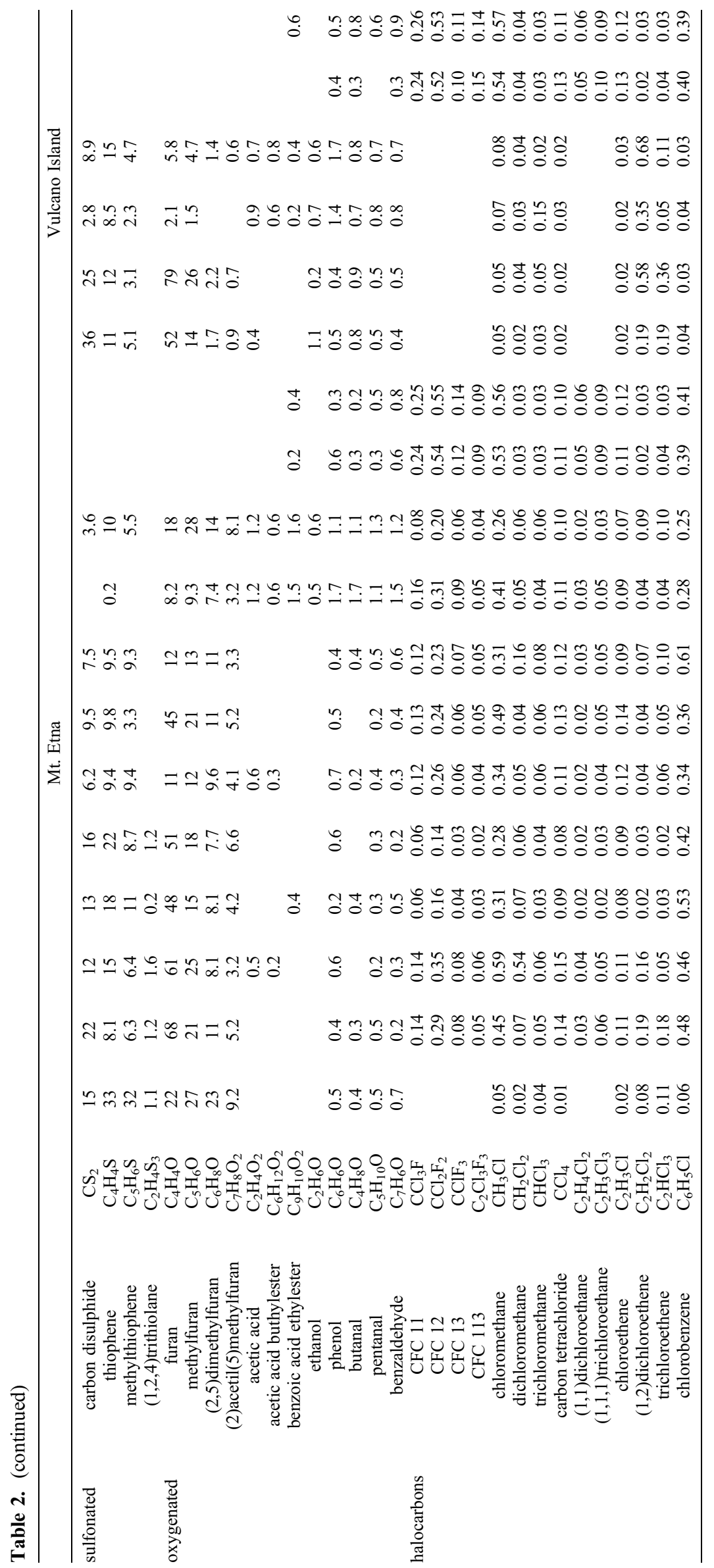




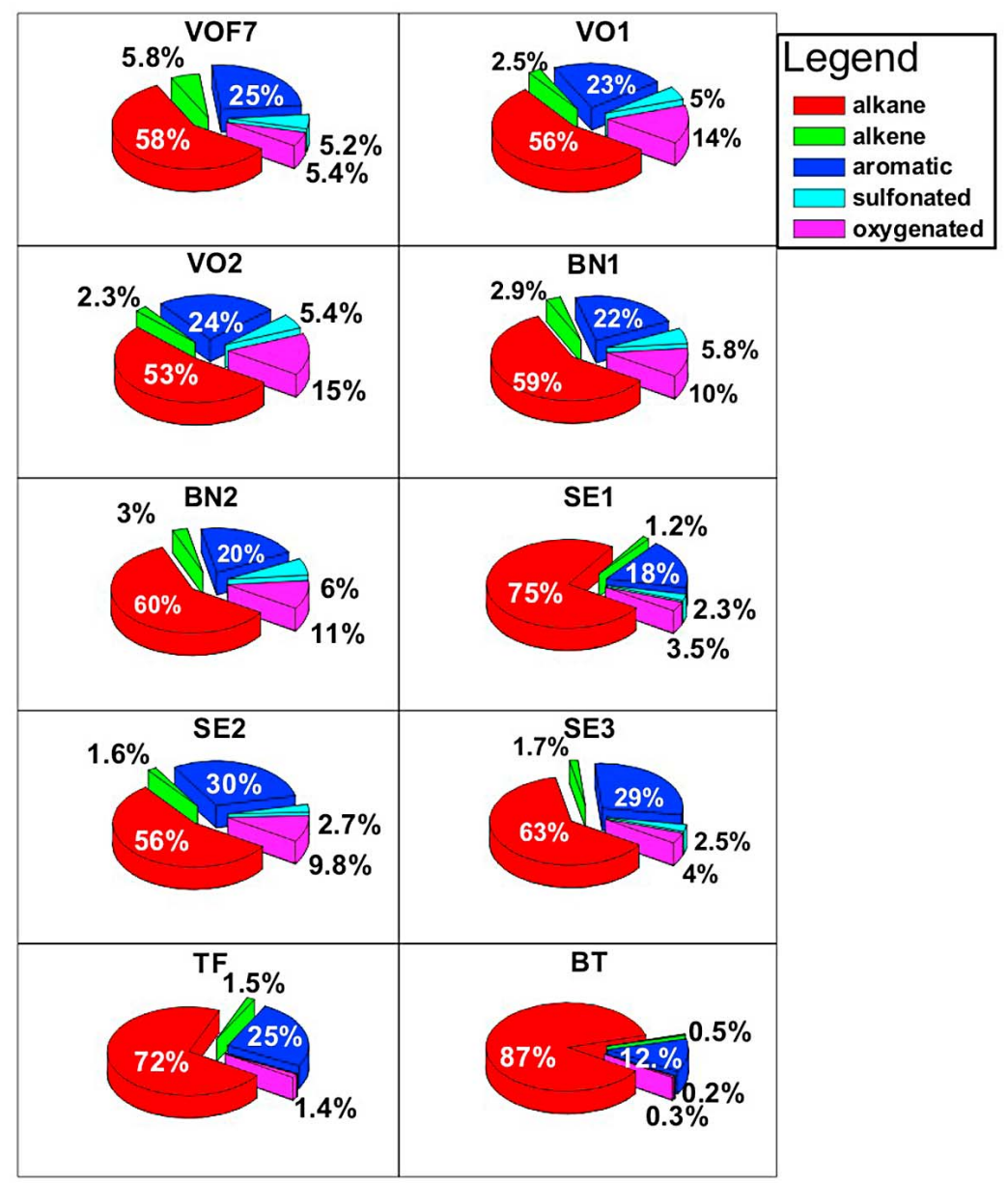

Figure 4. Pie diagrams showing the relative percentages of VOCs pertaining to alkane, alkene, aromatic, sulfonated and oxygenated groups in gas discharges from Mt. Etna volcano.

whereas naphthalene (from 0.2 to $11 \mathrm{ppbv}$ ) is the only PAH (polycyclic aromatic hydrocarbon) detected. Sulfonated compounds are mainly constituted of thiophenes $\left(\mathrm{C}_{4} \mathrm{H}_{4} \mathrm{~S}\right.$ and $\mathrm{C}_{5} \mathrm{H}_{6} \mathrm{~S}$ are up to 33 and $32 \mathrm{ppbv}$, respectively), and $\mathrm{CS}_{2}$ (up to $36 \mathrm{ppbv}$ ), whereas $\mathrm{C}_{2} \mathrm{H}_{4} \mathrm{~S}_{3}$, known as main constituent of floral fragrances [Frérot et al., 2008], has detectable concentrations $(\leq 1.6 \mathrm{ppbv})$ only in some samples from the Etna summit craters. Heterocycles $\left(\mathrm{C}_{4} \mathrm{H}_{4} \mathrm{O}, \mathrm{C}_{5} \mathrm{H}_{6} \mathrm{O}, \mathrm{C}_{6} \mathrm{H}_{8} \mathrm{O}\right.$ and $\mathrm{C}_{7} \mathrm{H}_{8} \mathrm{O}_{2}$ up to $79,28,23$ and 9.2 ppbv, respectively) largely dominate the composition of oxygenated compounds in the samples, whereas the sum of the measured esters, alcohols and aldehydes ( 8 different compounds) is $<10$ ppbv. All 14 halogenated species identified were in detectable amounts $(>0.01 \mathrm{ppbv})$ in most of the Etnean gases, whereas in the VOF7 sample and in those from Vulcano Island the fully halogenated halocarbons $\left(\mathrm{CCl}_{3} \mathrm{~F}, \mathrm{CCl}_{2} \mathrm{~F}_{2}, \mathrm{CClF}_{3}\right.$ and $\mathrm{C}_{2} \mathrm{Cl}_{3} \mathrm{~F}_{3}$ ) and $\mathrm{C}_{2} \mathrm{H}_{4} \mathrm{Cl}_{2}$ and $\mathrm{C}_{2} \mathrm{H}_{3} \mathrm{Cl}_{3}$ were below the detection limit.

[21] The VOC composition of the four air samples $\left(\mathrm{O}_{\text {air }}\right.$, $\mathrm{W}_{\text {air }}, \mathrm{V}_{\text {air }}$ and $\mathrm{C}_{\text {air }}$ ) are similar and show relatively low concentrations of aromatic (from 0.2 to $2.9 \mathrm{ppbv}$ ) and oxygenated (from 0.2 to $0.9 \mathrm{ppbv}$ ) compounds and terpenes (e.g., $\alpha$ pinene, limonene, camphene; not quantified), whereas halocarbons are at concentrations consistent (from 0.03 to
$0.57 \mathrm{ppbv}$ ) with those commonly measured in the atmosphere [Derwent et al., 1998; Butler et al., 1999; Mangani et al., 2000; Hall et al., 2002; Mangani et al., 2003; International Atomic Energy Agency, 2006].

\section{Discussion}

\subsection{Source Regions of Fluid Discharged From Mt. Etna and Vulcano Island}

[22] The chemical features of fluid discharges from volcanic systems are produced by a variety of primary sources, such as mantle, crust and magmatic degassing, and secondary processes that include gas-water-rock interactions, phase changes (mainly vapor-liquid) and mixing between deeporiginated fluids and sea- and/or groundwater. Volcanic fluids basically show two main components: 1) a deeporiginated 'magmatic' end-member, which prevails in summit crater exhalations of active volcanoes, and 2) a shallower "hydrothermal" end-member, lying above the magmaticdominated zone.

[23] The chemical composition of the fumarolic emissions from the summit Etnean craters is related to strong contribution of magmatic gases (mainly $\mathrm{CO}_{2}, \mathrm{SO}_{2}$ and $\mathrm{HCl}$ ) rapidly ascending from the deep degassing system throughout 


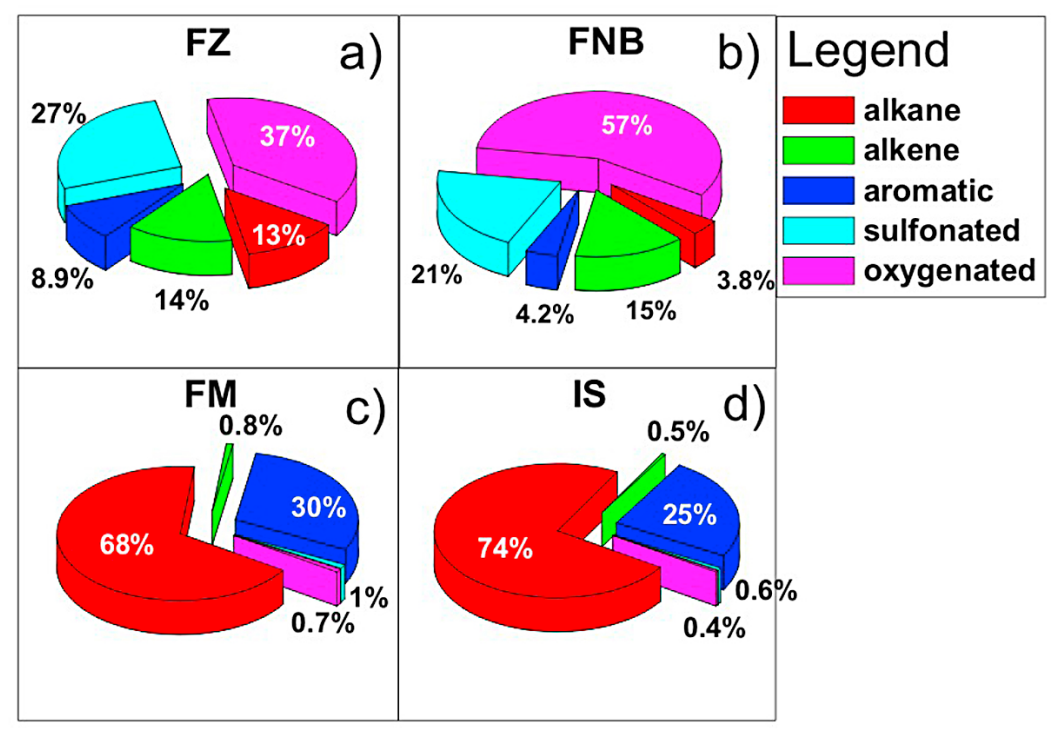

Figure 5. Pie diagrams showing the relative percentages of VOCs pertaining to alkane, alkene, aromatic, sulfonated and oxygenated groups in (a) FZ, (b) FNB, (c) FM, and (d) IS gas discharges from Vulcano Island.

high-permeability fracture, and gases produced by hightemperature gas-gas and gas-rock reactions $\left(\mathrm{H}_{2}, \mathrm{H}_{2} \mathrm{~S}\right.$ and $\mathrm{CO})$. These fumaroles (excepting VOF7) are also marked by significant amounts of atmospheric gases $\left(\mathrm{N}_{2}, \mathrm{O}_{2}\right.$ and $\left.\mathrm{Ar}\right)$ drained from the flanks of the craters by fracture systems, whereas the hydrothermal component, which was interpreted as the source of $\mathrm{CH}_{4}$ [Liotta et al., 2010], seems to be relatively low. The peripheral emissions (BT and TF; Figure 1), characterized by a significant $\mathrm{CH}_{4}$-enrichment (Table 1), are produced by boiling of a hydrothermal aquifer, mainly fed by meteoric water permeating through the fractured flanks [Liotta et al., 2010] that dissolves the highly soluble acidic species from the magmatic source.

[24] The crater fumaroles of Vulcano Island show dominating magmatic and high-temperature gases with minor contribution of hydrothermal fluids and air (Table 1), although relative proportions of the magmatic and hydrothermal end-members may vary in time depending on the status of volcanic activity [Paonita et al., 2002]. On the contrary, the exhalations from Levante beach discharge typical $\mathrm{SO}_{2-}, \mathrm{HCl}$ - and HF-free hydrothermal fluids, enriched in $\mathrm{CH}_{4}$ and air compounds, the latter being likely related to interaction with air saturated seawater. Our results are in agreement with the most reliable geochemical models of the volcanic-hydrothermal system of Vulcano [Chiodini et al., 1995; Tedesco et al., 1995], suggesting that the fumarolic discharges at Levante beach and La Fossa crater are fed from distinct fluid regions, i.e., a boiling hydrothermal reservoir and a magmatic(dominating)-hydrothermal degassing system, respectively.

\subsection{Origin of VOCs}

\subsubsection{Hydrocarbons}

[25] Organic compounds in volcanic fluids are generally interpreted as the result of hydrothermal contribution to the main magmatic-related fluid component. Hydrocarbons (e.g., alkanes, alkenes, aromatics) in hydrothermal environments are produced by 1) metabolic and biosynthetic activity of biological organisms (biogenesis), and 2) decomposition of pre-existing organic matter occurring at temperatures $\left(>150^{\circ} \mathrm{C}\right)$ too high for bacteria survival (thermogenesis) $[$ Des Marais et al., 1981; Rice and Claypool, 1981; Oremland et al., 1987; Galimov, 1988; Whiticar and Suess, 1990; Mango, 2000]. Notwithstanding the relatively high temperatures, volatiles produced by microbial activity such as VOCs can be released into the atmosphere [Schulz and Dickschat, 2007; Schulz et al., 2010], implying that air contaminated fumaroles may partly be affected by biogenic hydrocarbons.

[26] Hydrocarbons can abiogenically be produced in laboratory experimental runs and industrial processes though mechanisms that may include Fischer-Tropsch-type (FTT) reactions [Fischer and Tropsch, 1926] at temperatures $>200^{\circ} \mathrm{C}$, high pressures and on metal ( $\mathrm{Fe}, \mathrm{Ni}$ and $\mathrm{Co}$ ), oxide (magnetite) or carbide catalysts [Biloen and Sachtler, 1981; Anderson 1984; Galuszka et al., 1992; Foustoukos and Seyfried, 2004; McCollom and Seewald, 2006, 2007; Fu et al., 2007; Taran et al., 2007, 2010]. Theoretical approaches have shown that thermodynamic conditions of volcanichydrothermal fluid reservoirs are consistent with those required for abiogenic synthesis of organic compounds [Shock, 1990; Symonds and Reed, 1993; Wahrenberger, 1997; Shock and Schulte, 1998; Zolotov and Fegley, 1999; Zolotov and Shock, 2000; Wahrenberger et al., 2002]. Formation of abiogenic hydrocarbons was proposed to occur in a range of natural environments in the Earth's crust [Seward, 1974; Abrajano et al., 1988; Szatmari, 1989; Isidorov et al., 1990; Sugisaki and Mimura, 1994; Kenney, 1995; Basiuk and Navarro-González, 1996; Berndt et al., 1996; Giggenbach, 1997; Salvi and Williams-Jones, 1997; Gize, 1999; Kelley and Früth-Green, 2001; Sherwood Lollar et al., 2002; Taran et al., 2002; Taran and Cienfuegos, 


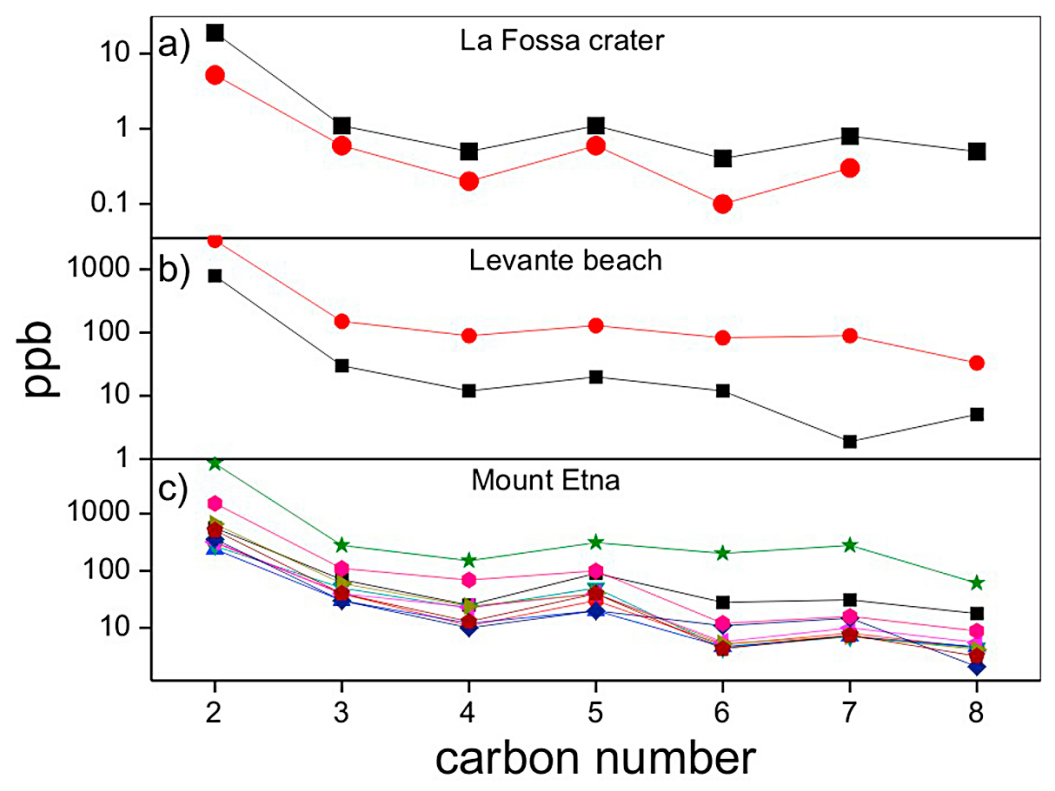

Figure 6. $\mathrm{C}_{2}-\mathrm{C}_{8}$-alkane distribution in gas discharges from (a) La Fossa crater, (b) Levante beach (Vulcano Island), and (c) Mt. Etna volcano.

2008; Etiope et al., 2011]. However, reliable geochemical parameters able to unequivocally identify abiogenic hydrocarbons in natural fluids have still not been identified.

[27] Light $\left(\mathrm{C}_{2}-\mathrm{C}_{6}\right)$ hydrocarbons occurring in lowtemperature gas discharges from Levante beach at Vulcano Island are ascribed to thermogenic processes [Mangani et al., 1991; Capaccioni et al., 1995, 2001]. Schwandner et al. [2004] found that the relative abundances of $\mathrm{C}_{7}-\mathrm{C}_{12}$ $n$-alkanes in fumarolic fluids from La Fossa crater has a modus at $\mathrm{C}_{8}$, followed by a strong decrease of $\mathrm{C}_{8+}$ concentrations resembling a Schulz-Flory type distribution [Satterfield and Huff, 1982], which is regarded as a indicator of catalytic Fischer-Tropsch synthesis [Salvi and WilliamsJones, 1997]. On this basis, hydrocarbons in these gases are suggested to be possibly deriving from an abiogenic source [Schwandner et al., 2004]. Our data show that the $\mathrm{C}_{2}-\mathrm{C}_{8}$ $n$-alkane distributions of the two samples from La Fossa crater (Figure 6a) are different with respect to the typical Shultz-Flory linear pattern, and are characterized by relatively high concentrations of alkanes with odd carbon number (pentanes and heptanes) consistent with those expected for hydrocarbon production by pyrolisis of kerogen [Pereira et al., 1982; Huizinga et al., 1988; Putschew et al., 1998]. The $n$-alkane distribution at Levante beach (Figure $6 \mathrm{~b}$ ) and Mt. Etna (Figure 6c) are similar to those of the La Fossa gases. This behavior supports the idea that in volcanichydrothermal systems thermogenesis can be regarded as a common genetic process for these organic compounds. Useful insights into the genetic mechanism of $n$-alkanes are provided by the carbon isotopic signatures of the $\mathrm{C}_{1}-\mathrm{C}_{3}$ alkane series [Des Marais et al., 1981, 1988; Chung et al., 1988; Sherwood Lollar et al., 2002, 2008; Potter et al., 2004; Fu et al., 2007; Taran et al. 2007, 2010; Proskurowski et al., 2008; McCollom et al., 2010]. Unfortunately, neither in the present study nor, to the best of our knowledge, in literature, are these data available for Mt. Etna and Vulcano fumaroles, likely because the abundances of such compounds are too low to allow isotopic analyses using methods adopted by most of the analytical laboratories.

[28] Production of alkenes by alkane dehydrogenation is favored under oxidizing conditions and relatively high temperatures [Giggenbach and Corrales-Soto, 1992; Seewald, 1994; Capaccioni et al., 1995, 2004, 2011; Taran and Giggenbach, 2003, 2004; Tassi et al., 2009a, 2009b], i.e., thermodynamic conditions characterizing the volcanichydrothermal systems of both Mt. Etna and Vulcano Island. This would explain the relatively high concentrations of alkenes measured in our gas samples, significantly higher than those commonly found in hydrothermal fluids [Tassi, 2004]. High contents of aromatic compounds, such as those measured in all the analyzed gas samples (Figures 4 and 5), are consistent with those measured in gas discharges from various hydrothermal and volcanic systems worldwide [Simoneit et al., 1988; Giggenbach and Corrales-Soto, 1992; Darling, 1998; Capaccioni et al., 2004; Tassi, 2004; Tassi et al., 2007, 2009a, 2010b]. Formation of aromatic compounds may proceed through catalytic "reforming" processes, such as dehydrogenation of cycloalkanes, dehydrocyclization of alkanes and cyclization of acetylene [Tamers, 1976; Rucker et al., 1986; Mango, 1994; Capaccioni et al., 1995; Mériaudeau and Naccache, 1997]. These reactions are favored in presence of catalytic agents, such as free acids, allumosilicates and sulfur gas species, largely available in a volcanic environment, where monoaromatics may also form from thermal decomposition of alkylated aromatic compounds with long side chains [Savage and Klein, 1987; Smith and Savage, 1991; Kissin, 1998]. Efficiency of oxidative aromatization of methane to produce benzene was proven only experimentally [Claridge et al., 1992]. The ubiquitous occurrence of aromatic compounds, especially benzene, in 
volcanic-hydrothermal fluids is likely related to the high stability of the aromatic ring $\left(\mathrm{C}_{6} \mathrm{H}_{6}\right)$ under a large range of temperature and redox conditions [Katritzky et al., 1990], although the abundance of aromatics in natural fluids also depends on i) the type of source matter [Leythaeuser et al., 1979], and ii) migration-related compositional fractionation [Thompson, 1987]. Catalytic degradation of methylated mono-aromatic compounds [McCollom et al., 2001], involving benzaldehyde and phenol that were measured at significant concentrations in most gas emissions of the present study (Table 2), is likely the cause for the high ratios between benzene and the sum of its methylated derivatives (up to 55). Zolotov and Shock [2000] found that in a cooling volcanic gas, naphthalene, which is consistently present of all the samples from both Mt. Etna and Vulcano, and other PAHs have the thermodynamic potential to be formed via Fischer-Tropsch reaction. However, this process is efficient at temperatures $<250^{\circ} \mathrm{C}$, i.e., lower than the outlet temperature of some of the sampled fumaroles. This suggests that formation of naphthalene in these fluids mostly depends on thermal degradation of organic matter.

\subsubsection{Oxygenated and Sulfonated Compounds}

[29] In volcanic gases, production of $\mathrm{CS}_{2}$ may occur through sulfonation processes involving compounds typical of magmatic degassing $\left(\mathrm{SO}_{2}\right.$ and $\left.\mathrm{CO}_{2}\right)$, as well as gases from secondary gas-water-rock interactions $\left(\mathrm{H}_{2} \mathrm{~S}\right.$ and $\left.\mathrm{CH}_{4}\right)$ [Petherbridge et al., 2002]. Among the various catalytic processes able to synthesize thiophenes [Southward et al., 1998; Tomov et al., 2000; Li et al., 2008], ring closure of dienes, known as Paal-Knorr synthesis, through addition of $\mathrm{H}_{2} \mathrm{~S}$ in presence of $\mathrm{H}^{+}$and metals [Campaigne and Foye, 1952], is to be considered the most reliable genetic mechanism in active volcanoes that are rich in these catalysts [Tassi et al., 2010a]. Similarly, ring closure of oxygenated alkenes may represent the main genetic mechanism for furans, which are the most abundant fraction of oxygenated species (Table 2). Natural abiotic formation of furans in soil can also be related to oxidation of organic matter induced by iron (III) and hydrogen peroxide in the presence of chloride [Huber et al., 2010]. Alkene oxidation may produce alcohols, aldehydes and esters [Muenow, 1973], a process that may be favored at depth by oxidizing conditions determined by the presence of magmatic compounds, although it can also occur when ascending fumarolic fluids approach the surface, where free $\mathrm{O}_{2}$ is available due to air contamination. Acetic acid may also form by methylation of formate produced by $\mathrm{CO}$ dissociation. Oxygenated compounds were detected in the air samples at concentrations similar to those of the fumaroles, thus their presence in fumarolic fluids, especially in those from Mt. Etna, can also be directly due to air contamination.

[30] Previous studies [Tassi et al., 2010a] have found that in volcanic-hydrothermal fluids the concentrations of thiophenes show an inverse correlation with species released from magmatic degassing, whereas they are enriched in fluids from hydrothermal systems, where high $\mathrm{H}_{2} \mathrm{~S}$ concentrations and reducing conditions favor thiophene formation. In contrast, furans have a strong correlation with magmatic fluids. In the present study, the gas samples are characterized by comparable abundances of sulfonated and oxygenated heteroaromatics (Table 2), suggesting that both magmatic and hydrothermal sources significantly contribute to the gas discharges of Mt. Etna and Vulcano Island.

\subsubsection{Halogenated Compounds}

[31] Halogenated compounds, intensively produced during several industrial processes, occur in atmospheric air at significant concentrations due to their extraordinary environmental stability. Jordan et al. [2000] measured CFCs in gases from different volcanic systems, including Mt. Etna and Vulcano Island, at concentrations equal to background air. Frische et al. [2006], on the basis of analysis of fumarolic gases from Momotombo, Cerro Negro and Mombacho volcanoes (Nicaragua), excluded the presence of significant concentrations of geogenic halocarbons. According to these results, halocarbons are commonly used as tracers for the atmospheric component within a fumarole sample. Some authors [Stoiber et al., 1971; Cadle et al., 1979; Isidorov et al., 1990; Isidorov et al., 1992] suggested that reaction between magmatic hydrogen halides (e.g., $\mathrm{HCl}$ and $\mathrm{HF}$ ) and organic compounds are capable to produce halocarbons in active volcanoes. Occurrence of volcanogenic halocarbons may explain the relative enrichment of CFC-11 found by Schwandner et al. [2004] in gases discharged from La Fossa crater, although thermodynamic calculations seem to exclude this hypothesis [Symonds et al., 1988]. In the present study, particular attention was paid to halocarbons to understand whether the presence of these compounds in volcanic environment could be related to a geogenic source. As also shown by the VOC analysis of the air samples from Mt. Etna and Vulcano Island (Table 2), significant concentrations of halogenated compounds are present in the atmosphere. Considering that atmospheric components typically contribute to the composition of fumarolic gases at various degrees, a correct evaluation of the origin of halocarbons in volcanic fluids needs a reliable quantification of air contamination in the collected samples. Nitrogen, i.e., the main air constituent, may partially derive from organic rich sediments buried within subducting material [Jenden et al., 1988], especially in volcanoes located along plate boundaries [Giggenbach, 1996] such as Vulcano, whereas $\mathrm{O}_{2}$ is rapidly consumed during subsurface gas-water-rock interactions. Neon, which can be considered entirely atmospheric, was below the detection limit $(0.001 \mathrm{mmol} / \mathrm{mol})$ in several samples. According to these considerations, Ar is to be regarded as the best candidate for evaluating the atmospheric fraction in the fumarolic samples, although radiogenic contributions cannot be excluded, at least in the Vulcano gases where ${ }^{40} \mathrm{Ar} /{ }^{36} \mathrm{Ar}$ ratios higher than that of air (295) were occasionally measured [Tedesco and Nagao, 1996]. Assuming that Ar concentration in air is $9.3 \mathrm{mmol} / \mathrm{mol}$, the air fraction $\left(\mathrm{A}_{\mathrm{f}}\right)$ in fumarolic samples ranges from $0.7 \%$ to $1.8 \%$ in Vulcano gases, whereas that in fumaroles from Mt. Etna, excepting the VOF7 sample $\left(\mathrm{A}_{\mathrm{f}}=1.9 \%\right)$, is between $25.7 \%$ and $62.8 \%$. Concentrations in fumaroles of halogenated compounds deriving from air contribution are calculated considering the $A_{f}$ values and the measured concentrations of halogenated compounds in air (mean values of the two air samples collected from each investigated volcano). The Etnean gases have measured concentrations (meas) of most hydrogenated halocarbons $\left(\mathrm{C}_{2} \mathrm{H}_{3} \mathrm{Cl}, \mathrm{C}_{2} \mathrm{HCl}_{3}, \mathrm{CHCl}_{3}, \mathrm{C}_{2} \mathrm{H}_{2} \mathrm{Cl}_{2}, \mathrm{CH}_{2} \mathrm{Cl}_{2}\right.$, $\mathrm{CH}_{3} \mathrm{Cl}$, and $\mathrm{C}_{6} \mathrm{H}_{5} \mathrm{Cl}$ ) and $\mathrm{CCl}_{4}$ significantly higher than those expected considering air as their unique source (exp) (Figure 7). The meas values of these halocarbons in the Vulcano fumaroles are up to three orders of magnitude higher than the exp ones (Figure 8). On the contrary, the differences 


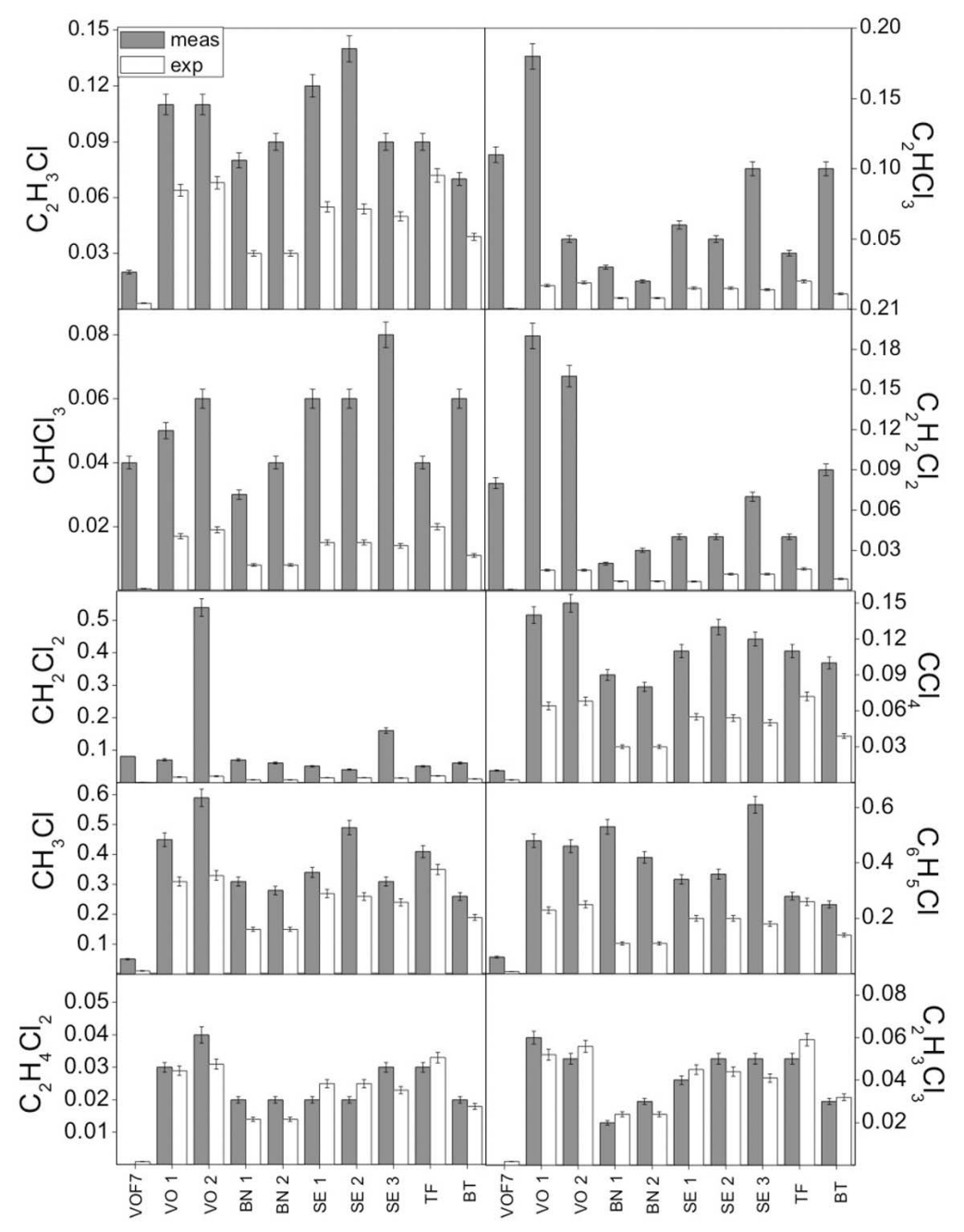

Figure 7. Comparison between measured (meas) and expected (exp) concentrations (in ppbv) of hydrogenated halocarbons $\left(\mathrm{C}_{2} \mathrm{H}_{3} \mathrm{Cl}, \mathrm{C}_{2} \mathrm{HCl}_{3}, \mathrm{CHCl}_{3}, \mathrm{C}_{2} \mathrm{H}_{2} \mathrm{Cl}_{2}, \mathrm{CH}_{2} \mathrm{Cl}_{2}, \mathrm{CH}_{3} \mathrm{Cl}, \mathrm{C}_{6} \mathrm{H}_{5} \mathrm{Cl}, \mathrm{C}_{2} \mathrm{H}_{4} \mathrm{Cl}_{2}\right.$, and $\mathrm{C}_{2} \mathrm{H}_{3} \mathrm{Cl}_{3}$ ) and $\mathrm{CCl}_{4}$ in fumaroles from Mt. Etna volcano. Exp values, i.e., the concentrations of hydrogenated halocarbons deriving from air contamination of fumaroles, are calculated on the basis of the air fraction $\left(\mathrm{A}_{\mathrm{f}}\right)$ present in the gas samples.

between meas and exp concentrations for $\mathrm{C}_{2} \mathrm{H}_{3} \mathrm{Cl}_{3}$ and $\mathrm{C}_{2} \mathrm{H}_{4} \mathrm{Cl}_{2}$ are in the range of the analytical error for Etnean gases (Figure 7), while they are below the detection limit for those of Vulcano (Figure 8). It is worth noting that the exp values for Vulcano samples are likely overestimated, since $A_{f}$ calculation may be affected by an error deriving by presence of radiogenic Ar. Consequently, the halocarbon excess characterizing Vulcano fluids may be even higher than that estimated with our method. These results clearly show that, even in aerated fumaroles, such as those from Mt. Etna, most hydrogenated halocarbons and $\mathrm{CCl}_{4}$ have an extraatmospheric source. This is in disagreement with previous authors [Jordan et al., 2000; Jordan, 2003; Frische et al., 2006], who reported concentrations of several HCFCs and CFCs in fumaroles and lava gas samples from various volcanoes, including Vulcano and Mt. Etna, equal to or below background air. However, interactions between concentrated alkaline solutions and halocarbons are known to have significant degradation effects on these organic species [Needs and Selvendran, 1993; Yu et al., 1996]. Therefore, halocarbon quantitative analysis in gases stored in the headspace of Giggenbach flasks, i.e., the sampling method used by both Jordan et al. [2000] and Jordan [2003] and Frische et al. [2006], may be affected by loss of analytes. Comparison between meas and exp concentrations of CFCs for Etnean gases (Figure 9) seems to indicate that the geogenic fraction of these compounds is not significant. This indication cannot be confirmed by the CFC composition in Vulcano fumaroles, since the concentrations of these gas species, as well as their exp values, were below the detection limit (Figure 10). However, analyses of CFCs and HCFCs in air extracted from Antartic firn [Sturrock et al., 2002] showed that $\mathrm{CCl}_{3} \mathrm{~F}$, $\mathrm{CCl}_{2} \mathrm{~F}_{2}, \mathrm{CClF}_{3}$ and $\mathrm{C}_{2} \mathrm{Cl}_{3} \mathrm{~F}_{3}$ were not detectable in samples older than the 1930s, when the industrial production of these gases started, suggesting that their origin is entirely synthetic. In contrast, the same authors reported the occurrence of significant concentrations of $\mathrm{CCl}_{4}$ and in samples of preindustrial age. This supports our results clearly indicating 


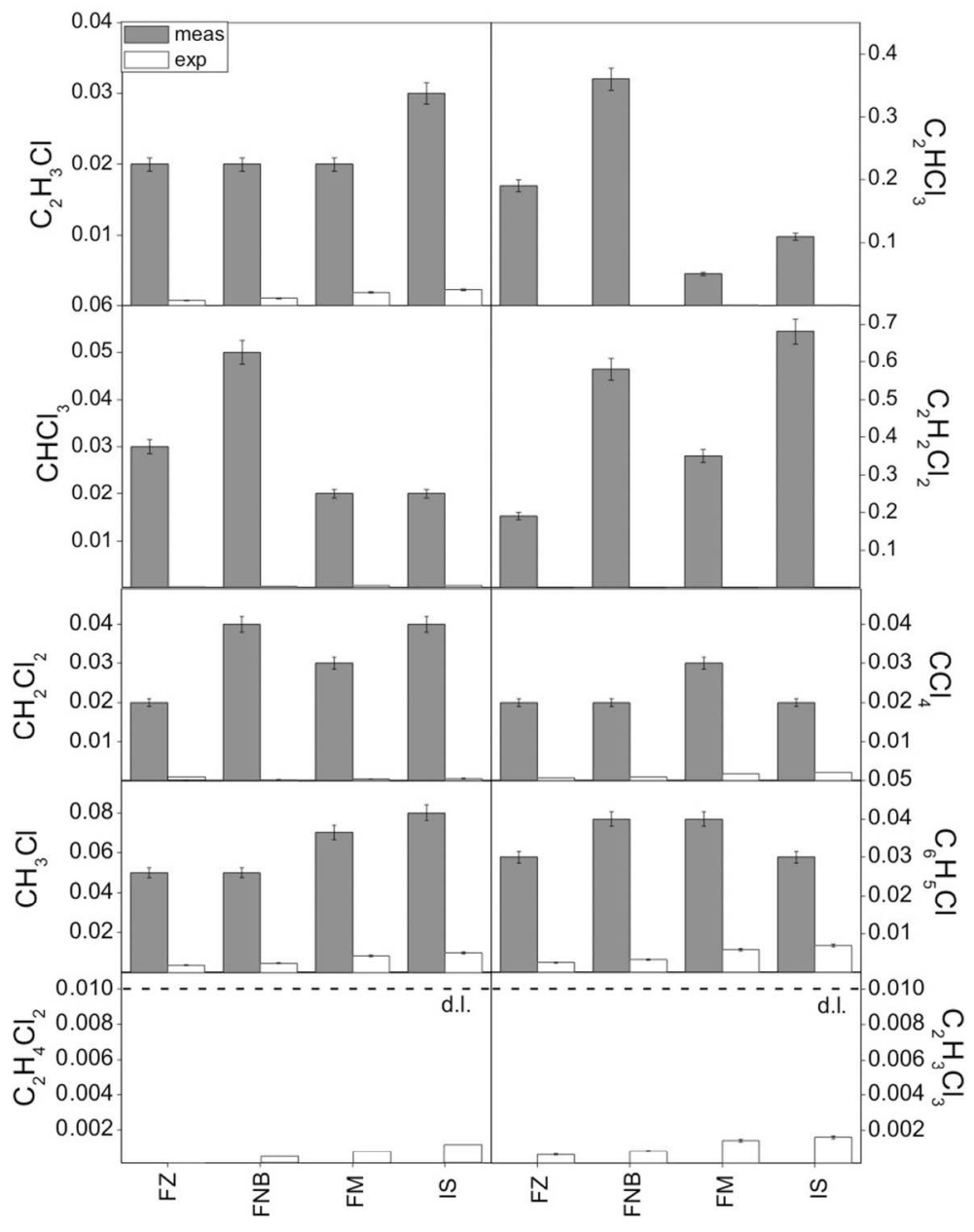

Figure 8. Comparison between measured (meas) and expected (exp) concentrations (in ppbv) of hydrogenated halocarbons $\left(\mathrm{C}_{2} \mathrm{H}_{3} \mathrm{Cl}, \mathrm{C}_{2} \mathrm{HCl}_{3}, \mathrm{CHCl}_{3}, \mathrm{C}_{2} \mathrm{H}_{2} \mathrm{Cl}_{2}, \mathrm{CH}_{2} \mathrm{Cl}_{2}, \mathrm{CH}_{3} \mathrm{Cl}, \mathrm{C}_{6} \mathrm{H}_{5} \mathrm{Cl}, \mathrm{C}_{2} \mathrm{H}_{4} \mathrm{Cl}_{2}\right.$, and $\mathrm{C}_{2} \mathrm{H}_{3} \mathrm{Cl}_{3}$ ) and $\mathrm{CCl}_{4}$, in fumaroles from Vulcano Island.

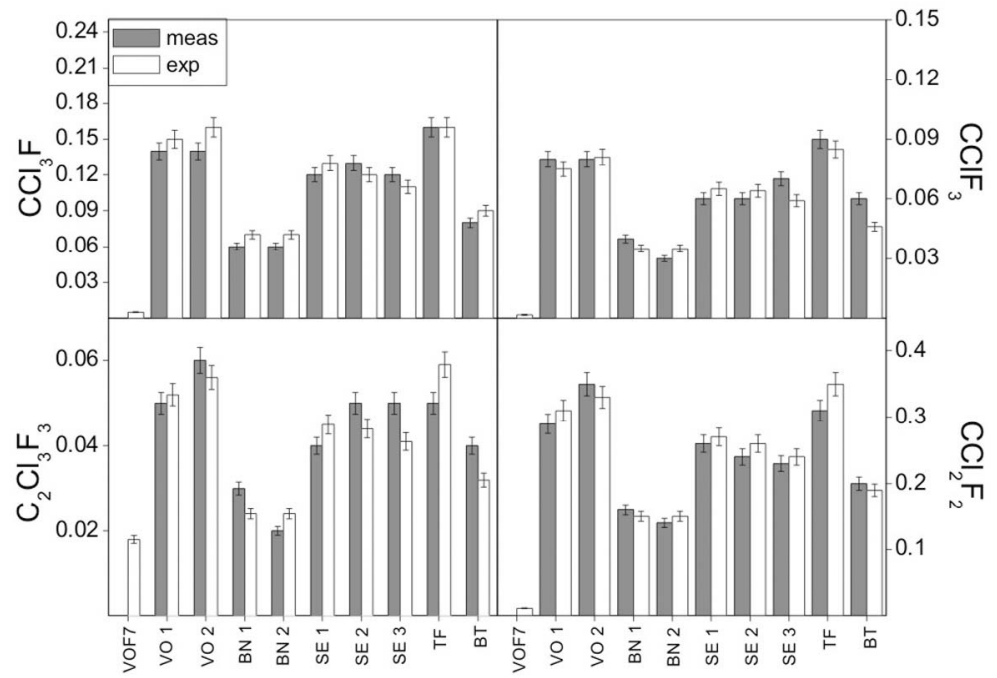

Figure 9. Comparison between measured (meas) and expected (exp) concentrations (in ppbv) of CFCs $\left(\mathrm{CCl}_{3} \mathrm{~F}, \mathrm{CClF}_{3}, \mathrm{C}_{2} \mathrm{Cl}_{3} \mathrm{~F}_{3}\right.$, and $\left.\mathrm{CCl}_{2} \mathrm{~F}_{2}\right)$ in fumaroles from Mt. Etna. 


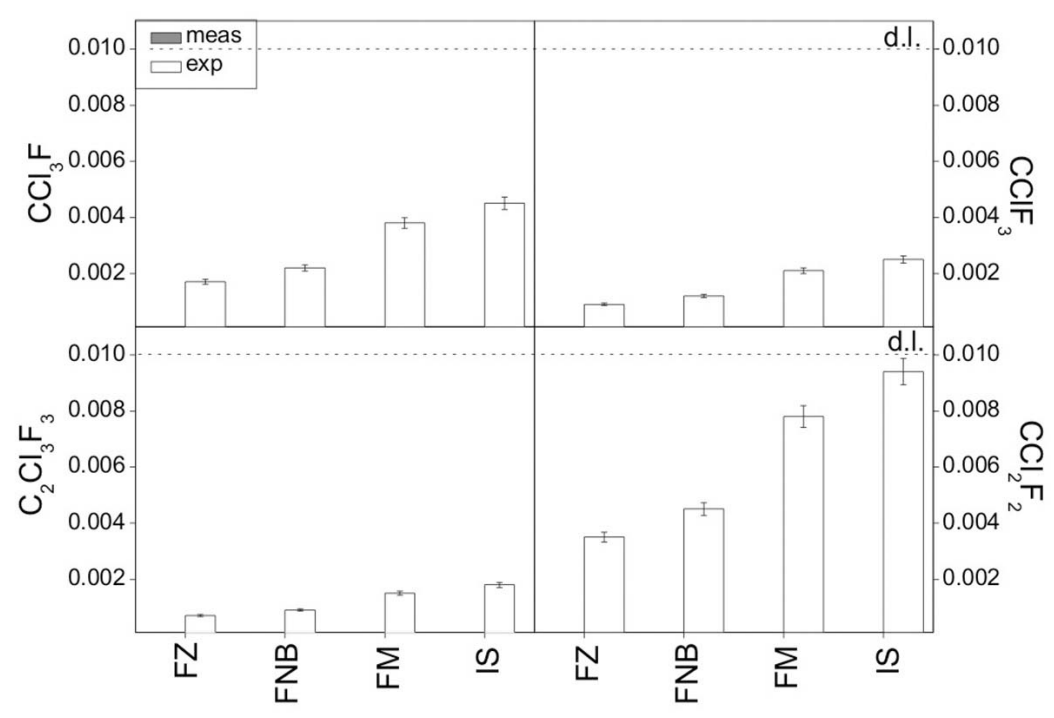

Figure 10. Comparison between measured (meas) and expected (exp) concentrations (in ppbv) of CFCs $\left(\mathrm{CCl}_{3} \mathrm{~F}, \mathrm{CClF}_{3}, \mathrm{C}_{2} \mathrm{Cl}_{3} \mathrm{~F}_{3}\right.$, and $\left.\mathrm{CCl}_{2} \mathrm{~F}_{2}\right)$ in fumaroles from Vulcano Island.

that hydrogenated halocarbons and $\mathrm{CCl}_{4}$ can derive from a natural source.

\section{Conclusions}

[32] VOCs pertaining to alkane, alkene and aromatic groups, as well as their O-, S- and $\mathrm{Cl}(\mathrm{F})$-substituted compounds, were identified in a large range of concentrations in volcanic-hydrothermal fluids from Mt. Etna and Vulcano Island. Pyrolysis of organic matter buried in sediments interacting with the ascending magmatic fluids, is likely the main genetic mechanism for alkanes that, at their turn, are converted to alkene and aromatic compounds through catalytic reactions, such as dehydrogenation and dehydroaromatization, respectively. Occurrence of abiogenic light hydrocarbons cannot be definitely assessed (or excluded) without the support of carbon and hydrogen isotopic data whose analyses are prevented by their low concentrations. The chemical-physical conditions characterizing both Mt. Etna and Vulcano volcanic-hydrothermal systems, i.e., relatively high temperatures, highly acidic and oxidizing conditions and abundance of inorganic sulfur gases, favor the formation of S- and O-bearing heteroaromatic compounds. In this highly reactive environment, oxidation of hydrocarbons to produce minor amounts of alcohols, esters and aldehydes may occur. Alternatively, addition of these compounds to the fumarolic fluids could derive from air contamination.

[33] Our data, compared with those expected for background air, have shown that in active volcanic systems, where large amounts of hydrogen halides and metal catalysts are available, geogenic halocarbons can be produced in significant amounts through halogenation of both methane and alkenes. This reaction seems to be not efficient when alkanes are involved, likely because these compounds are chemically inert, especially in comparison to alkenes, and are present in volcanic gases at concentrations relatively low compared to methane. CFC concentrations are consistent with background air in fumaroles from Mt. Etna, thus the occurrence of geogenic CFCs seems be excluded, in agreement with the lack of detectable concentrations of these compounds in air samples of pre-industrial age. This suggests that processes of complete halogenation of organic compounds in a natural environment, even when conditions are favorable such as those of volcanic-hydrothermal systems, is not efficient, i.e., significantly lower than that required for natural production of $\mathrm{HCFCs}$.

[34] Halocarbons are chemical species of great interest to global warming and climate change issues. Contradictory results are reported by different studies and suggests that compositional data of halocarbons in volcanic fluids, to be used for an estimation of the input of these compounds to the atmosphere from natural sources, are to be taken with caution. Further investigations on these issues, aimed to improve the halocarbon quantification in volcanic gases even at very low concentrations, are strongly recommended, especially when considering the importance their geochemical cycle may have at global scale.

[35] Acknowledgments. J. de Gouw and two anonymous reviewers are warmly thanked for significantly improving an early version of the manuscript. Many thanks are due to the director of Istituto Nazionale Geofisica e Vulcanologia (INGV) of Catania, D. Patanè, and to O. Consoli for kindly providing the scientific base (Etna Volcano Observatory) for the sampling group at Mt. Etna. The Ente Parco dell'Etna is gratefully acknowledged for allowing this scientific investigation. This work was supported in part by a Project of Ciudad de la Energia (Spain). Sincere thanks also go to N. Bobrowski, G. Giuffrida, R. Avino, C. Cardellini, E. Bagnato, G. Tamburello, M. Liuzzo, M. Liotta and W. D'Alessandro for their help during the Etnean gas sampling, while I. Cinelli, M. Cuadrado and A. Credoz are acknowledged for their assistance during the sampling at Vulcano Island.

\section{References}

Abrajano, T. A., N. C. Sturchio, J. K. Bohlke, G. L. Lyon, P. J. Poreda, and C. M. Stevens (1988), Methane-hydrogen gas seeps, Zambales ophiolite, Philippines: Deep or shallow origin?, Chem. Geol., 71, 211-222, doi:10.1016/0009-2541(88)90116-7.

Allard, P., B. Behncke, A. D'Amico, M. Neri, and S. Gambino (2006), Mount Etna 1993-2005: Anatomy of an evolving eruptive cycle, Earth Sci. Rev., 78, 85-114, doi:10.1016/j.earscirev.2006.04.002.

Anderson, R. B. (1984), The Fischer-Tropsch Synthesis, Academic, San Diego, Calif. 
Andreae, M. O. (1996), Methylhalide emissions from savanna fires in southern Africa, J. Geophys. Res., 101, 23,603-23,613, doi:10.1029/ 95JD01733.

Astaf'ev, V. P., A. K. Makhmudov, and A. I. Zhelonkin (1973), Significance of isobutane/butane ratios in hydrocarbon gases in searching for petroluem (according to Baltic and Bielorussian data), Tr. Vses. Neft. Nauchno-Issled. Geologorazved. Inst., 338, 35-38.

Barberi, F., L. Civetta, P. Gasparini, F. Innocenti, R. Scandone, and L. Villari (1974), Evolution of a section of the Africa-Europe plate boundary: Paleomagnetic and volcanological evidence from Sicily, Earth Planet. Sci. Lett., 22, 123-132, doi:10.1016/0012-821X(74)90072-7.

Barberi, F., G. Neri, M. Valenza, and L. Villari (1991), 1987-1990 unrest at Vulcano, Acta Vulcanol., 1, 95-106.

Basiuk, V. A., and R. Navarro-González (1996), Possible role of ash-gas clouds in the Earth's prebiotic chemistry, Origins Life Evol. Biospheres, 26, 173-194, doi:10.1007/BF01809854.

Beccaluva, L., R. Gabbianelli, R. Lucchini, P. L. Rossi, and C. Savelli (1985), Petrology and K/Ar ages of volcanic dredged from the Eolian seamonts: Implications for geodynamic evolution of the southern Tyrrhenian basin, Earth Planet. Sci. Lett., 74, 187-208, doi:10.1016/0012-821X(85) 90021-4.

Berndt, M. E., D. E. Allen, and W. E. Seyfried (1996), Reduction of $\mathrm{CO}_{2}$ during serpentinization of olivine at $300^{\circ} \mathrm{C}$ and 500 bar, Geology, 24 351-354, doi:10.1130/0091-7613(1996)024<0351:ROCDSO > 2.3.CO;2.

Biloen, P., and W. M. H. Sachtler (1981), Mechanism of hydrocarbon synthesis over Fischer-Tropsch catalysts, in Advances in Catalysis, vol. 30, edited by D. D. Eley, H. Piens, and P. B. Weisz, pp. 165-216, Academic, San Diego, Calif., doi:10.1016/S0360-0564(08)60328-4.

Bolognesi, L., and F. D'Amore (1993), Isotopic variation of the hydrothermal system on Vulcano Island, Italy, Geochim. Cosmochim. Acta, 57, 2069-2082, doi:10.1016/0016-7037(93)90094-D.

Bonaccorso, A. (2002), Ground deformation of the southern sector of the Aeolian Islands volcanic arc from geodetic data, Tectonophysics, 351, 181-192, doi:10.1016/S0040-1951(02)00163-4.

Brasseur, G., and C. Granier (1992), Mount Pinatubo aerosols, chlorofluorocarbons, and ozone depletion, Science, 257, 1239-1242, doi:10.1126/ science.257.5074.1239.

Brune, W. (1996), Ozone depletion: There's safety in numbers, Nature, 379, 486-487, doi:10.1038/379486a0.

Burnett, B. J., T. P. Fischer, Z. D. Sharp, D. R. Hilton, and D. de Leeuw (2003), Volatile light hydrocarbon compositions of the Central American Arc and Yellowstone National Park, EOS Trans. AGU, 84(46), Fall Meet. Suppl., Abstract V21C-0534.

Butler, J. H., M. Battle, M. L. Bender, S. A. Montzka, A. D. Clarke, E. S. Saltzman, C. M. Sucher, J. P. Severinghaus, and J. W. Elkins (1999), A record of atmospheric halocarbons during the twentieth century from polar firn air, Nature, 399, 749-755, doi:10.1038/21586.

Cadle, R. D., A. L. Lazrus, B. J. Huebert, L. E. Heidt, W. I. Rose, D. C. Woods, R. L. Chuan, R. L. Stoiber, D. B. Smith, and R. A. Zielinski (1979), Atmospheric implications of studies of central American volcanic eruption clouds, J. Geophys. Res., 84(C11), 6961-6968, doi:10.1029/ JC084iC11p06961.

Campaigne, E., and W. O. Foye (1952), The synthesis of 2,5 diarylthiophenes, J. Org. Chem., 17, 1405-1412.

Capaccioni, B., and F. Mangani (2001), Monitoring of active but quiescent volcanoes using light hydrocarbon distribution in volcanic gases: The results of 4 years of discontinous monitoring in the Campi Flegrei (Italy), Earth Planet. Sci. Lett., 188, 543-555, doi:10.1016/S0012-821X(01) 00338-7.

Capaccioni, B., M. Martini, F. Mangani, L. Giannini, G. Nappi, and F. Prati (1993), Light hydrocarbons in gas emissions from volcanic areas and geothermal fields, Geochem. J., 27(1), 7-17, doi:10.2343/geochemj.27.7.

Capaccioni, B., M. Martini, and F. Mangani (1995), Light hydrocarbons in hydrothermal and magmatic fumaroles - Hints of catalytic and thermal reactions, Bull. Volcanol., 56(8), 593-600.

Capaccioni, B., F. Tassi, and O. Vaselli (2001), Organic and inorganic geochemistry of low temperature gas discharges at the Levante beach, Vulcano Island, Italy, J. Volcanol. Geotherm. Res., 108(1-4), 173-185, doi:10.1016/S0377-0273(00)00284-5.

Capaccioni, B., Y. Taran, F. Tassi, O. Vaselli, G. Mangani, and J. L. Macias (2004), Source conditions and degradation processes of light hydrocarbons in volcanic gases: An example from El Chichón volcano (Chiapas State, Mexico), Chem. Geol., 206(1-2), 81-96, doi:10.1016/j.chemgeo. 2004.01.011.

Capaccioni, B., F. Aguilera, F. Tassi, T. Darrah, R. J. Poreda, and O. Vaselli (2011), Geochemical and isotopic evidences of magmatic inputs in the hydrothermal reservoir feeding the fumarolic discharges of Tacora volcano (nothern Chile), J. Volcanol. Geotherm. Res., 208, 77-85, doi:10.1016/j.jvolgeores.2011.09.015.
Capasso, G., R. Favara, and S. Inguaggiato (1997), Chemical features and isotopic composition of gaseous manisfestations on Vulcano Island, Aeolian Islands, Italy: An interpretative model of fluid circulation, Geochim. Cosmochim. Acta, 61, 3425-3440, doi:10.1016/S0016-7037(97)00163-4.

Carapezza, M., P. M. Nuccio, and M. Valenza (1981), Genesis and evolution of the fumaroles of Vulcano (Aeolian Islands, Italy): A geochemical model, Bull. Volcanol., 44, 547-563, doi:10.1007/BF02600585.

Chester, D. K., A. M. Duncan, J. E. Guest, and C. R. J. Kilburn (1985), Mount Etna: The Anatomy of a Volcano, Chapman and Hall, London, U. K.

Chiodini, G., R. Cioni, S. Falsaperla, A. Montalto, M. Guidi, and L. Marini (1992), Geochemical and seismological investigations at Vulcano (Aeolian Islands) during 1978-1989, J. Geophys. Res., 97(B7), 11,025-11,032, doi:10.1029/92JB00518.

Chiodini, G., R. Cioni, and L. Marini (1993), Reactions governing the chemistry of crater fumaroles from Vulcano Island, Italy, and implication for volcanic surveillance, Appl. Geochem., 8, 357-371, doi:10.1016/ 0883-2927(93)90004-Z.

Chiodini, G., R. Cioni, L. Marini, and C. Panichi (1995), Origin of the fumarolic fluids of Vulcano Island, Italy, and implications for the volcanic surveillance, Bull. Volcanol., 57, 99-110, doi:10.1007/BF00301400.

Chiodini, G., P. Allard, S. Caliro, and F. Parello (2000), ${ }^{18} \mathrm{O}$ exchange between steam and carbon dioxide in volcanic and hydrothermal gases: Implications for the source of water, Geochim. Cosmochim. Acta, 64, 2479-2488, doi:10.1016/S0016-7037(99)00445-7.

Chung, H. M., J. R. Gormly, and R. M. Squires (1988), Origin of gaseous hydrocarbons in subsurface environments: Theoretical considerations of carbon isotope distribution, Chem. Geol., 71, 97-104, doi:10.1016/ 0009-2541(88)90108-8.

Cicerone, R. J., R. S. Stolarski, and S. Walters (1974), Stratospheric ozone destruction by man-made chlorofluoromethanes, Science, 185 1165-1167, doi:10.1126/science.185.4157.1165.

Cioni, R., and F. D'Amore (1984), A genetic model for the crater fumaroles of Vulcano Island (Sicily, Italy), Geothermics, 13, 375-384, doi:10.1016/ 0375-6505(84)90051-8.

Claridge, J. B., M. H. L. Green, S. C. Tsang, and A. P. E. York (1992), Oxidative oligomerization of methane to aromatics, Appl. Catal., 89 103-116, doi:10.1016/0926-860X(92)80080-V.

Cronn, D. R., and W. Nutmagul (1982a), Characterization of trace gases in 1980 volcanic plumes of Mt. St. Helens, J. Geophys. Res., 87(C13), 11,153-11,160, doi:10.1029/JC087iC13p11153.

Cronn, D. R., and W. Nutmagul (1982b), Volcanic gases in the April 1979 Soufriere eruption, Science, 216, 1121-1123, doi:10.1126/science.216. 4550.1121.

Darling, W. G. (1998), Hydrothermal hydrocarbon gases: 1. Genesis and geothermometry, Appl. Geochem., 13(7), 815-824, doi:10.1016/S08832927(98)00013-4

Derwent, R. G., P. G. Simmonds, S. O’Doherty, and D. B. Ryall (1998), The impact of the Montreal Protocol on halocarbon concentrations in Northern Hemisphere baseline and European air masses at Mace Head, Ireland, over a ten year period from 1987 to 1996, Atmos. Environ., 32, 3689-3702, doi:10.1016/S1352-2310(98)00092-2.

Des Marais, D. J., J. H. Donchin, N. H. Nehring, and A. H. Truesdell (1981), Molecular carbon isotopic evidence for the origin of geothermal hydrocarbons, Nature, 292, 826-828, doi:10.1038/292826a0.

Des Marais, D. J., M. L. Stallard, N. L. Nehring, and A. H. Truesdell (1988), Carbon isotope geochemistry of hydrocarbons in the Cerro Prieto geothermal field, Baja California Norte, Mexico, Chem. Geol., 71, 159-167, doi:10.1016/0009-2541(88)90112-X.

Etiope, G., and P. Ciccioli (2009), Earth's degassing: A missing ethane and propane source, Science, 323, 478, doi:10.1126/science.1165904.

Etiope, G., K. R. Lassey, R. W. Klusman, and E. Boschi (2008), Reappraisal of the fossil methane budget and related emission from geologic sources, Geophys. Res. Lett., 35, L09307, doi:10.1029/2008GL033623.

Etiope, G., M. Schoell, and H. Hosgörmez (2011), Abiotic methane flux from the Chimaera seep and Tekirova ophiolites (Turkey): Understanding gas exhalation from low temperature serpentinization and implications for Mars, Earth Planet. Sci. Lett., 310(1-2), 96-104, doi:10.1016/j.eps1. 2011.08.001.

Farman, J. C., B. G. Gardiner, and J. D. Shanklin (1985), Large losses of total ozone in Antarctica reveal seasonal $\mathrm{ClO}_{x} / \mathrm{NO}_{x}$ interaction, Nature, 315, 207-210, doi:10.1038/315207a0.

Fiebig, J., A. B. Woodland, W. D’Allessandro, and W. Püttmann (2009), Excess methane in continental hydrothermal emissions is abiogenic, Geology, 37, 495-498, doi:10.1130/G25598A.1.

Fink, L. E. (1983), Comment on "Characterization of organic contaminants in environmental samples associated with the Mount St. Helens 1980 volcanic eruption", Environ. Sci. Technol., 17(5), 312-313, doi:10.1021/ es00111a016. 
Fischer, F., and H. Tropsch (1926), Die Erodolsynthese bei gewohnlichem druck aus den vergangsprodukten der kohlen, Brennstoff-Chemie, 7, 97-116.

Foustoukos, D. I., and W. E. Seyfried Jr. (2004), Hydrocarbons in hydrothermal vent fluids: The role of chromium-bearing catalysts, Science, 304, 1002-1005, doi:10.1126/science.1096033.

Frérot, E., A. Velluz, A. Bagnoud, and E. Delort (2008), Analysis of the volatile constituents of cooked petai beans (Parkia speciosa) using high-resolution GC/ToF-MS, Flavour Fragrance J., 23, 434-440, doi: $10.1002 /$ ffj. 1902 .

Frische, M., K. Garofalo, T. H. Hansteen, R. Borchers, and J. Harnisch (2006), The origin of stable halogenated compounds in volcanic gases, Environ. Sci. Pollut. Res., 13(6), 406-413, doi:10.1065/espr2006.01.291.

Fu, Q., B. Sherwood Lollar, J. Horita, G. Lacrampe-Couloume, and J. W. E. Seyfried (2007), Abiotic formation of hydrocarbons under hydrothermal conditions: Constraints from chemical and isotopic data, Geochim. Cosmochim. Acta, 71, 1982-1998, doi:10.1016/j.gca.2007.01.022.

Gaffney, J. S. (1995), Volcanic CFCs, Environ. Sci. Technol., 29(1), 8A, doi:10.1021/es00001a704.

Galimov, E. M. (1988), Sources and mechanisms of formation of gaseous hydrocarbons in sedimentary rocks, Chem. Geol., 71, 77-95, doi:10.1016/0009-2541(88)90107-6.

Galuszka, J., T. Sano, and J. A. Sawicki (1992), Study of carbonaceous deposits on Fischer-Tropsch oxide-supported iron catalysts, J. Catal., 136, 96-109, doi:10.1016/0021-9517(92)90109-U.

Gamlen, P. H., B. C. Lane, P. M. Midgley, and J. M. Steed (1986), The production and release to the atmosphere of $\mathrm{CCl}_{3} \mathrm{~F}$ and $\mathrm{CCl}_{2} \mathrm{~F}_{2}$ (chlorofluorocarbons CFC 11 and CFC 12), Atmos. Environ., 20, 1077-1085, doi:10.1016/0004-6981(86)90139-3.

Gerlach, T. (1991), Etna's greenhouse pump, Nature, 351, 352-353, doi:10.1038/351352a0.

Giggenbach, W. F. (1996), Chemical composition of volcanic gases, in Monitoring and Mitigation of Volcano Hazards, edited by R. Scarpa and R. Tilling, pp. 221-256, Springer, Berlin, doi:10.1007/978-3-64280087-0 7 .

Giggenbach, W. F. (1997), The origin and evolution of fluids in magmatichydrothermal systems, in Geochemistry of Hydrothermal Ore Deposits, 3rd ed., edited by H. L. Barnes, pp. 737-796, John Wiley, New York.

Giggenbach, W. F., and R. Corrales-Soto (1992), Isotopic and chemical composition of water and steam discharges from volcanic-magmatichydrothermal systems of the Guanacaste Geothermal Province, Costa Rica, Appl. Geochem., 7, 309-332, doi:10.1016/0883-2927(92)90022-U.

Giggenbach, W. F., N. Garcia, A. Londono, L. Rodriguez, N. Rojas, and M. L. Calvache (1990), The chemistry of fumarolic vapor and thermalspring discharges from the Nevado del Ruiz volcanic-magmatichydrothermal system, Colombia, J. Volcanol. Geotherm. Res., 42(1-2), 13-39, doi:10.1016/0377-0273(90)90067-P.

Gize, A. P. (1999), Organic alteration in hydrothermal sulfide ore deposits, Econ. Geol., 94, 967-979, doi:10.2113/gsecongeo.94.7.967.

Granieri, D., M. L. Carapezza, G. Chiodini, R. Avino, S. Caliro, M. Ranaldi, T. Ricci, and L. Tarchini (2006), Correlated increase in $\mathrm{CO}_{2}$ fumarolic content and diffuse emission from La Fossa crater (Vulcano, Italy): Evidence of volcanic unrest or increasing gas release from a stationary deep magma body?, Geophys. Res. Lett., 33, L13316, doi:10.1029/2006GL026460.

Gribble, G. W. (2010), Naturally Occurring Organohalogen Compounds A Comprehensive Update, Prog. in the Chem. of Org. Nat. Prod., vol. 91, edited by A. D. Kinghorn, H. Falk, and J. Kobayashi, Springer, Vienna, doi:10.1007/978-3-211-99323-1.

Hall, B. D., et al. (2002), Halocarbons and other atmospheric traces species, in Climate Monitoring and Diagnostics Laboratory Summary Report 2000-2001, edited by D. B. King et al., pp. 106-135, NOAA Oceanic and Atmos. Res., Boulder, Colo.

Harnisch, J., and N. Hoehne (2002), Comparison of emissions estimates derived from atmospheric measurements with national estimates of HFCs, PFCs and SF6, Environ. Sci. Pollut. Res., 9(5), 315-319, doi:10.1007/BF02987573.

Harnisch, J., D. de Jager, J. Gale, and O. Stobbe (2002), Halogenated compounds and climate change: Future emission levels and reduction costs, Environ. Sci. Pollut. Res., 9(6), 369-374, doi:10.1007/BF02987583.

Huber, S. G., K. Kotte, H. F. Schöler, and J. Williams (2009), Natural abiotic formation of trihalomethanes in soil: Results from laboratory studies and field samples, Environ. Sci. Technol., 43, 4934-4939, doi:10.1021/ es8032605.

Huber, S. G., S. Wunderlich, H. F. Schöler, and J. Williams (2010), Natural abiotic formation of furans in soil, Environ. Sci. Technol., 44, 5799-5804, doi:10.1021/es100704g.
Huizinga, B. J., Z. A. Aizenshtat, and K. E. Peters (1988), Programmed pyrolisis-gas chromatography of artificially matured Green River kerogen, Energy Fuels, 2(1), 74-81, doi:10.1021/ef00007a011.

Inn, E. C. Y., J. F. Vedder, E. P. Condon, and D. O'Hara (1981), Gaseous constituents in the plume from eruptions of Mount St. Helens, Science, 211, 821-823, doi:10.1126/science.211.4484.821.

Intergovernmental Panel on Climate Change (2001), Climate Change 2001: The Scientific Basis, edited by J. T. Houghton et al., Cambridge Univ. Press, Cambridge, U. K.

International Atomic Energy Agency (2006), Use of Chlorofluorocarbons in Hydrology: A Guidebook, 277 pp., Int. At. Energy Agency, Vienna.

Isidorov, V. A., and I. G. Zenkevich (1985), The atmosphere organic components in the regions of volcanic activity [in Russian], Dokl. Akad. Nauk SSSR, 280(1), 223-227.

Isidorov, V. A., I. G. Zenkevich, and B. V. Ioffe (1990), Volatile organic compounds in solfataric gases, J. Atmos. Chem., 10(3), 329-340, doi:10.1007/BF00053867.

Isidorov, V. A., I. G. Zenkevich, and G. A. Karpov (1992), Volatile organic compounds in steam-gas outflows of several volcanoes and hydrothermal systems in Kamchatka, Vulkanol. Seismol., 13(3), 287-293.

Jenden, P. D., I. R. Kaplan, R. J. Poreda, and H. Craig (1988), Origin of nitrogen-rich gases in the California Great Valley: Evidence from helium, carbon and nitrogen isotope ratios, Geochim. Cosmochim. Acta, 52, 851-861, doi:10.1016/0016-7037(88)90356-0.

Jordan, A. (2003), Volcanic formation of halogenated organic compounds, in The Handbook of Environmental Chemistry, edited by G. W. Gribble, pp. 121-139, Springer, Berlin.

Jordan, A., J. Harnisch, R. Borchers, F. N. Le Guern, and H. Shinohara (2000), Volcanogenic halocarbons, Environ. Sci. Technol., 34(6), 1122-1124, doi:10.1021/es990838q.

Katritzky, A. R., M. Balasubramanian, and M. Siskin (1990), Aqueous high-temperature chemistry of carbo- and heterocycles. 2. Monosubstituted benzenes: Benzyl alcohol, benzaldehyde and benzoic acid, Energy Fuels, 4, 499-505, doi:10.1021/ef00023a016.

Keene, W. C., et al. (1999), Composite global emissions of reactive chlorine from anthropogenic and natural sources: Reactive chlorine emissions inventory, J. Geophys. Res., 104(D7), 8429-8440, doi:10.1029/ 1998JD100084.

Keller, J. (1980), The island of Vulcano, in The Aeolian Islands: An Active Volcanic Arc in the Mediterranean Sea, edited by L. Villari, pp. 29-74, Rend. Soc. Ital. Mineral. Petrol., Milan, Italy.

Kelley, D. S., and G. L. Früth-Green (2001), Volatile lines of descent in submarine plutonic environments: Insights from stable isotope and fluid inclusion analyses, Geochim. Cosmochim. Acta, 65, 3325-3346, doi:10.1016/S0016-7037(01)00667-6.

Kenney, J. K. (1995), Comment on "Mantle hydrocarbons: Abiotic or biotic?" by R. Sugisaki and K. Mimura, Geochim. Cosmochim. Acta, 59, 3857-3858, doi:10.1016/0016-7037(95)00283-6.

Keppler, F., R. Eiden, V. Niedan, J. Pracht, and H. Schöler (2000), Halocarbons produced by natural oxidation processes during degradation of organic matter, Nature, 403, 298-301, doi:10.1038/35002055.

Keppler, F., R. Brochers, J. Pracht, S. Rheinberger, and H. F. Schöler (2002), Natural formation of vinyl chloride in the terrestrial environment, Environ. Sci. Technol., 36, 2479-2483, doi:10.1021/es0156111.

Khalil, M. A. K., R. M. Moore, D. B. Harper, J. M. Lobert, D. J. Erickson, V. Koropalov, W. T. Sturges, and W. C. Keene (1999), Natural emissions of chlorine-containing gases: Reactive chlorine emissions inventory, J. Geophys. Res., 104(D7), 8333-8346, doi:10.1029/1998JD100079.

Kissin, Y. V. (1998), Catagenesis of light aromatic compounds in petroleum, Org. Geochem., 29, 947-962, doi:10.1016/S0146-6380(98) 00144-2.

Kiyosu, Y., N. Asada, and Y. Yoshida (1992), Origin of light hydrocarbon gases from the Matsukawa geothermal area in Japan, Chem. Geol., 94 321-329, doi:10.1016/S0009-2541(10)80034-8.

Laturnus, F., F. C. Adams, and C. Wiencke (1998), Methyl halides from Antarctic microalgae, Geophys. Res. Lett., 25(6), 773-776, doi:10.1029/ 98GL00490.

Leifer, R., K. Sommers, and S. F. Guggenheim (1981), Atmospheric trace gas measurements with a new clean air sampling system, Geophys. Res. Lett., 8(10), 1079-1081, doi:10.1029/GL008i010p01079.

Leythaeuser, D., R. G. Schaefer, C. Cornford, and B. Weiner (1979), Generation and migration of light hydrocarbon $\left(\mathrm{C}_{2}-\mathrm{C}_{7}\right)$ in sedimentary basin, Org. Geochem., 1, 191-204, doi:10.1016/0146-6380(79)90022-6.

Li, Q., Y. Xu, C. Liu, and J. Kim (2008), Catalytic synthesis of thiophene from reaction of furan and hydrogen sulfide, Catal. Lett., 122, 354-358, doi:10.1007/s10562-007-9389-x.

Liotta, M., A. Paonita, A. Caracausi, M. Martelli, A. Rizzo, and R. Favara (2010), Hydrothermal processes governing the geochemistry of the crater 
fumaroles at Mount Etna volcano (Italy), Chem. Geol., 278, 92-104, doi:10.1016/j.chemgeo.2010.09.004.

Lobert, J. M., W. C. Keene, J. A. Logan, and R. Yevich (1999), Global chlorine emissions from biomass burning: Reactive chlorine emissions inventory, J. Geophys. Res., 104(D7), 8373-8389, doi:10.1029/ 1998JD100077.

Lovelock, J. E. (1975), Natural halocarbons in the air and in the sea, Nature, 256, 193-194, doi:10.1038/256193a0.

Mangani, F., A. Cappiello, B. Capaccioni, and M. Martini (1991), Sampling and analysis of light hydrocarbons in volcanic gases, Chromatographia, 32(9-10), 441-444, doi:10.1007/BF02327975.

Mangani, F., M. Maione, L. Lattanzi, and I. Arduini (2000), Atmospheric measurements of the halogenated hydrocarbons involved in global change phenomena, Atmos. Environ., 34, 5303-5309, doi:10.1016/ S1352-2310(00)00224-7.

Mangani, G., A. Berloni, and M. Maione (2003), "Cold” solid-phase microextraction method for the determination of volatile halocarbons present in the atmosphere at ultra-trace levels, J. Chromatogr. A, 988, 167-175, doi:10.1016/S0021-9673(02)02082-4.

Mango, F. D. (1994), The origin of light hydrocarbons in petroleum: Ring preference in the closure of carbocyclic rings, Geochim. Cosmochim. Acta, 58, 895-901, doi:10.1016/0016-7037(94)90513-4.

Mango, F. D. (2000), The origin of light hydrocarbons, Geochim. Cosmochim. Acta, 64, 1265-1277, doi:10.1016/S0016-7037(99)00389-0.

Martini, M. (1993), Water and fire: Vulcano Island from 1977 to 1991, Geochem. J., 27, 297-303, doi:10.2343/geochemj.27.297.

Martini, M. (1996), Chemical characters of the gaseous phase in different stages of volcanism: Precursors and volcanic activity, in A Monitoring and Mitigation of Volcano Hazard, edited by P. Scarpa and R. I. Tilling, pp. 199-219, Springer, Berlin, doi:10.1007/978-3-642-80087-0_6.

McCollom, T. M., and J. S. Seewald (2006), Carbon isotope composition of organic compounds produced by abiotic synthesis under hydrothermal conditions, Earth Planet. Sci. Lett., 243, 74-84, doi:10.1016/j.eps1. 2006.01.027.

McCollom, T. M., and J. S. Seewald (2007), Abiotic synthesis of organic compounds in deep-sea hydrothermal environments, Chem. Rev., 107, 382-401, doi: $10.1021 /$ cr0503660.

McCollom, T. M., J. S. Seewald, and B. R. T. Simoneit (2001), Reactivity of monocyclic aromatic compounds under hydrothermal conditions, Geochim. Cosmochim. Acta, 65, 455-468, doi:10.1016/S0016-7037(00) 00533-0.

McCollom, T. M., B. Sherwood Lollar, G. Lacrampe-Couloume, and J. S. Seewald (2010), The influence of carbon source on abiotic organic synthesis and carbon isotope fractionation under hydrothermal conditions, Geochim. Cosmochim. Acta, 74, 2717-2740, doi:10.1016/j.gca.2010.02. 008 .

McCulloch, A., P. M. Midgley, and P. Ashford (2003), Releases of refrigerant gases (CFC-12, HCFC-22 and HFC-134a) to the atmosphere, Atmos. Environ., 37, 889-902, doi:10.1016/S1352-2310(02)00975-5.

Mercalli, G. (1891), Cenni topografici-geologici dell'isola di Vulcano e storia delle sue eruzioni, Ann. Uff. Cent. Meteorol. Geodin. Ital., 12 , 76-118.

Mériaudeau, P., and C. Naccache (1997), Dehydrocyclization of alkanes over zeolite-supported metal catalysts: Monofunctional and bifunctional route, Catal. Rev., Sci. Eng., 39, 5-48, doi:10.1080/ 01614949708006467.

Molina, M. J., and F. S. Rowland (1974), Stratospheric sink for chlorofluoromethanes: Chlorine atom catalyzed destruction of ozone, Nature, 249 810-812, doi:10.1038/249810a0.

Montegrossi, G., F. Tassi, O. Vaselli, A. Buccianti, and K. Garofalo (2001), Sulphur species in volcanic gases, Anal. Chem., 73, 3709-3715, doi:10.1021/ac001429b.

Muenow, D. W. (1973), High temperature mass spectrometric gas-release studies of Hawaiian volcanic glass: Pele's Tears, Geochim. Cosmochim. Acta, 37, 1551-1561, doi:10.1016/0016-7037(73)90090-2.

Needs, P. W., and R. R. Selvendran (1993), Avoiding oxidative degradation during sodium hydroxide/methyl iodide-mediated carbohydrate methylation in dimethyl sulfoxide, Carbohydr. Res., 245(1), 1-10, doi:10.1016/ 0008-6215(93)80055-J.

Neri, M., and V. Acocella (2006), The 2004-2005 Etna eruption: Implications for flank deformation and structural behavior of the volcano, J. Volcanol. Geotherm. Res., 158, 195-206, doi:10.1016/j.jvolgeores.2006. 04.022 .

Neri, M., V. Acocella, and B. Behncke (2004), The role of the Pernicana Fault System in the spreading of Mt. Etna (Italy) during the 2002-2003 eruption, Bull. Volcanol., 66, 417-430, doi:10.1007/s00445-003-0322-x.

Neri, M., F. Mazzarini, S. Tarquini, B. Bisson, I. Isola, B. Behncke, and M. T. Pareschi (2008), The changing face of Mount Etna's summit area documented with Lidar technology, Geophys. Res. Lett., 35, L09305, doi:10.1029/2008GL033740.

Ogniben, L. (1966), Lineamenti idrogeologici dell'Etna, Riv. Miner. Siciliana, 100-102, 151-174.

Oremland, R., L. G. Miller, and M. J. Whiticar (1987), Sources and flux of natural gases from Mono Lake, California, Geochim. Cosmochim. Acta, 51, 2915-2929, doi:10.1016/0016-7037(87)90367-X.

Panichi, C., and P. Noto (1992), Isotopic and chemical composition of water, steam and gas samples of the natural manifestations of the island of Vulcano (Aeolian Arc, Italy), Acta Vulcanol., 2, 297-312.

Paonita, A., R. Favara, P. M. Nuccio, and F. Sortino (2002), Genesis of fumarolic emissions as inferred by isotope mass balances: $\mathrm{CO}_{2}$ and water at Vulcano Island, Italy, Geochim. Cosmochim. Acta, 66, 759-772, doi:10.1016/S0016-7037(01)00814-6.

Pereira, W. E., C. E. Rostad, H. E. Taylor, and J. M. Klein (1982), Characterization of organic contaminants in environmental samples associated with Mount St. Helens 1980 volcanic eruption, Environ. Sci. Technol., 16(7), 387-396, doi:10.1021/es00101a005.

Petherbridge, J. R., P. W. May, G. M. Fuge, K. N. Rosser, and M. N. R. Ashfold (2002), In situ plasma diagnostics of the chemistry behind sulfur doping of CVD diamond films, Diamond Relat. Mater., 11(3-6), 301-306, doi:10.1016/S0925-9635(01)00576-3.

Porshnev, N. V., and V. B. Bondarev (1989), Hydrocarbon of the C1-C11 range in high-temperature geotherms - Quantitative variations and pathways of formation, Dokl. Akad. Nauk SSSR, 306(3), 708-712.

Potter, J., A. H. Rankin, and P. J. Treloar (2004), Abiogenic FischerTropsch synthesis of hydrocarbons in alkaline igneous rocks: Fluid inclusion, textural and isotopic evidence from the Lovozero complex, N.W. Russia, Lithos, 75, 311-330, doi:10.1016/j.lithos.2004.03.003.

Proskurowski, G., M. Lilley, J. S. Seewald, G. I. Fruh-Green, E. J. Olson, S. P. Sylva, and D. S. Kelley (2008), Abiogenic hydrocarbon production at Lost City hydrothermal field, Science, 319, 604-607, doi:10.1126/ science.1151194.

Putschew, A., C. Schaeffer-Reiss, P. Schaeffer, M. P. Koopmans, J. De Leeuw, M. D. Lewan, J. S. Sinninghe Damsté, and J. R. Maxwell (1998), Release of sulfur- and oxygen-bound components from a sulfurrich kerogen during simulated maturation by hydrous pyrolysis, Org. Geochem., 29(8), 1875-1890, doi:10.1016/S0146-6380(98)00191-0.

Rasmussen, R. A., and L. E. Rasmussen (1980), Trace gases of volcanic origin, Eos Trans. $A G U, 61(6), 67$.

Rasmussen, R. A., M. A. K. Khalil, S. A. Penkett, and T. J. Casadevall (1981), Analysis of trace gases from Mt. St. Helens volcanic ash, Eos Trans. $A G U, 62(8), 81$.

Rice, D. D., and G. E. Claypool (1981), Generation, accumulation, and resource potential of biogenic gas, AAPG Bull., 65, 5-25.

Rowland, F. S., and M. J. Molina (1994), Ozone depletion: 20 years after the alarm, Chem. Eng. News, 72, 8-13.

Rucker, T. G., M. A. Logan, T. M. Gentle, E. L. Muetterties, and G. A. Somorjai (1986), Conversion of acetylene to benzene over palladium single-crystal surfaces. 1. The low-pressure stoichiometric and the highpressure catalytic reactions, J. Phys. Chem., 90(12), 2703-2708, doi:10.1021/j100403a029.

Rudolph, J. (1995), The tropospheric distribution and budget of ethane, J. Geophys. Res., 100(D6), 11,369-11,381, doi:10.1029/95JD00693.

Rudolph, J., K. von Czapiewski, and R. Koppmann (2000), Emissions of methyl chloroform $\left(\mathrm{CH}_{3} \mathrm{CCl}_{3}\right)$ from biomass burning and the tropospheric methyl chloroform budget, Geophys. Res. Lett., 27(13), 1887-1890, doi:10.1029/1999GL011178

Salvi, S., and A. E. Williams-Jones (1997), Fischer-Tropsch synthesis of hydrocarbons during sub-solidus alteration of the Strange Lake peralkaline granite, Quebec/Labrador, Canada, Geochim. Cosmochim. Acta, 61, 83-99, doi:10.1016/S0016-7037(96)00313-4.

Satterfield, C. N., and G. A. Huff (1982), Carbon number distribution of Fischer-Tropsch products formed on an iron catalyst in a slurry reactor, J. Catal., 73, 187-197, doi:10.1016/0021-9517(82)90092-6.

Savage, P. E., and M. T. Klein (1987), Asphaltene reaction pathways. 2. Pyrolysis of n-pentadecylbenzene, Ind. Eng. Chem. Res., 26, 488-494, doi:10.1021/ie00063a015.

Schiano, P., R. Clocchiatti, L. Ottolini, and T. Busà (2001), Transition of Mount Etna lavas from a mantle-plume to an island-arc magmatic source, Nature, 412, 900-904, doi:10.1038/35091056.

Schulz, S., and J. S. Dickschat (2007), Bacteria volatiles: The smell of small organisms, Nat. Prod. Rep., 24(4), 814-842, doi:10.1039/b507392h.

Schulz, S., J. S. Dickschat, B. Kunze, I. Wagner-Dobler, R. Diestel, and F. Sasse (2010), Biological activity of volatiles from marine and terrestrial bacteria, Mar. Drugs, 8, 2976-2987, doi:10.3390/md8122976.

Schwandner, F. M., T. M. Seward, A. P. Gize, P. A. Hall, and V. J. Dietrich (2004), Diffuse emission of organic trace gases from the flank and crater 
of a quiescent active volcano (Vulcano, Aeolian Islands, Italy), J. Geophys. Res., 109, D04301, doi:10.1029/2003JD003890.

Seewald, J. S. (1994), Evidence for metastable equilibrium between hydrocarbons under hydrothermal conditions, Nature, 370, 285-287, doi: $10.1038 / 370285 \mathrm{a} 0$.

Seward, T. M. (1974), Equilibrium and oxidation potential in geothermal waters at Broadlands, New Zealand, Am. J. Sci., 274, 190-192, doi:10.2475/ajs.274.2.190

Sherwood Lollar, B., T. D. Westgate, J. A. Ward, G. F. Slater, and G. Lacrampe-Couloume (2002), Abiogenic formation of alkanes in the Earth's crust as a minor source for global hydrocarbon reservoirs, Nature, 416, 522-524, doi:10.1038/416522a.

Sherwood Lollar, B., G. Lacrampe-Couloume, K. Voglesonger, T. C. Onstott, L. M. Pratt, and G. F. Slater (2008), Isotopic signatures of $\mathrm{CH}_{4}$ and higher hydrocarbon gases from Precambrian Shield sites: A model for abiogenic polymerization of hydrocarbons, Geochim. Cosmochim. Acta, 72, 4778-4795, doi:10.1016/j.gca.2008.07.004.

Shirey, R. (1999), Selecting the appropriate SPME fiber for your application needs, Pub. T499232, Supelco Inc., Bellefonte, Pa.

Shock, E. L. (1990), Geochemical constraints of the origin of organic compounds in hydrothermal systems, Origins Life Evol. Biosphere, 20, 331-367, doi:10.1007/BF01808115.

Shock, E. L., and M. D. Schulte (1998), Organic synthesis during fluid mixing in hydrothermal systems, J. Geophys. Res., 103, 28,513-28,527, doi:10.1029/98JE02142.

Sicardi, L. (1940), Il recente ciclo dell'attività fumarolica dell''isola di Vulcano, Bull. Volcanol., 7, 85-139, doi:10.1007/BF02994895.

Simoneit, B. R. T., O. E. Kawka, and M. Brault (1988), Origin of gases and condensates in the Guaymas Basin hydrothermal system (Gulf of California), Chem. Geol., 71, 169-182, doi:10.1016/0009-2541(88)90113-1.

Smith, C. M., and P. E. Savage (1991), Reactions of polycyclic alkylaromatics: Structure and reactivity, AIChE J., 37, 1613-1624, doi:10.1002/ aic. 690371104.

Southward, B. W. L., L. S. Fuller, G. J. Hutchings, R. W. Joyner, and R. A. Stewart (1998), Comments on the mechanism of the vapour-phase catalytic synthesis of thiophenes, Catal. Lett., 55, 207-210, doi:10.1023/ A: 1019082928758 .

Stoiber, R. E., D. C. Leggett, T. F. Jenkins, R. P. Murrmann, and W. I. Rose (1971), Organic compounds in volcanic gas from Santiaguito volcano, Guatemala, Geol. Soc. Am. Bull., 82(8), 2299-2302, doi:10.1130/00167606(1971)82[2299:OCIVGF]2.0.CO;2

Sturrock, G. A., D. M. Etheridge, C. M. Trudinger, P. J. Fraser, and A. M. Smith (2002), Atmospheric histories of halocarbons from analysis of Antartic firn air: Major Montreal Protocol species, J. Geophys. Res., 107(D24), 4765, doi:10.1029/2002JD002548.

Sugisaki, R., and K. Mimura (1994), Mantle hydrocarbons: Abiotic or biotic?, Geochim. Cosmochim. Acta, 58, 2527-2542, doi:10.1016/00167037(94)90029-9.

Sugisaki, R., and K. Nagamine (1995), Evolution of light hydrocarbon gases in subsurface processes: Constraints from chemical equilibrium, Earth Planet. Sci. Lett., 133(1-2), 151-161, doi:10.1016/0012-821X (95)00065-K.

Symonds, R. B., and M. H. Reed (1993), Calculation of multicomponent chemical equilibria in gas-solid-liquid systems: Calculation methods, thermochemical data, and applications to studies of high-temperature volcanic gases with examples from Mount St. Helens, Am. J. Sci., 293, 758-864, doi:10.2475/ajs.293.8.758.

Symonds, R. B., W. I. Rose, and M. H. Reed (1988), Contribution of Cl-bearing and F-bearing gases to the atmosphere by volcanos, Nature, 334, 415-418, doi:10.1038/334415a0.

Szatmari, P. (1989), Petroleum formation by Fischer-Tropsch synthesis in plate tectonics, AAPG Bull., 73, 989-998.

Tamers, M. A. (1976), Total synthesis benzene and its derivatives as major gasoline extenders, Science, 193, 231-233, doi:10.1126/science.193. 4249.231.

Tanguy, J. C., M. Condomines, and G. Kieffer (1997), Evolution of the Mount Etna magma: Constraints on the present feeding system and eruptive mechanism, J. Volcanol. Geotherm. Res., 75, 221-250, doi:10.1016/ S0377-0273(96)00065-0.

Taran, Y. A., and E. Cienfuegos (2008), Inverse isotopic trend in hydrocarbons from fumarolic gases of Everman volcano, Socorro Island, Mexico, Geochim. Cosmochim. Acta, 72, A935.

Taran, Y. A., and W. F. Giggenbach (2003), Geochemistry of light hydrocarbons in subduction-related volcanic and hydrothermal fluids, in Volcanic, Geothermal, and Ore-Forming Fluids: Rulers and Witnesses of Processes within the Earths, edited by S. F. Simmons and I. Graham, pp. 61-74, Soc. Econ. Geol., Littleton, Colo.

Taran, Y. A., and W. F. Giggenbach (2004), Evidence of metastable equilibrium between hydrocarbons in volcanic gases, in Water-Rock
Interaction, edited by R. B. Wanty and R. R. Seal, pp. 193-195, A. A. Balkema, Leiden, Netherlands.

Taran, Y. A., T. P. Fisher, E. Cienfuegos, and P. Morales (2002), Geochemistry of hydrothermal fluids from an intraplate ocean island: Everman volcano, Socorro Island, Mexico, Chem. Geol., 188, 51-63, doi:10.1016/ S0009-2541(02)00061-X.

Taran, Y. A., G. A. Kliger, and V. S. Sevastyanov (2007), Carbon isotope effects in the open-system Fischer-Tropsch synthesis, Geochim. Cosmochim. Acta, 71, 4474-4487, doi:10.1016/j.gca.2007.06.057.

Taran, Y. A., G. A. Kliger, E. Cienfuegos, and A. N. Shuykin (2010), Carbon and hydrogen isotopic compositions of products of open-system catalytic hydrogenation of $\mathrm{CO}_{2}$ : Implications for abiogenic hydrocarbons in Earth's crust, Geochim. Cosmochim. Acta, 74(21), 6112-6125, doi:10.1016/j.gca.2010.08.012.

Tassi, F. (2004), Fluidi in ambiente vulcanico: Evoluzione temporale dei parametri composizionali e distribuzione degli idrocarburi leggeri in fase gassosa, $\mathrm{PhD}$ thesis, Univ. of Florence, Florence, Italy.

Tassi, F., O. Vaselli, B. Capaccioni, G. Montegrossi, F. Barahona, and A. Caprai (2007), Scrubbing processes and chemical equilibria controlling the composition of light hydrocarbons in natural gas discharges: An example from the geothermal fields of Salvador, Geochem. Geophys. Geosyst., 8, Q05008, doi:10.1029/2006GC001487.

Tassi, F., F. Aguilera, O. Vaselli, E. Medina, D. Tedesco, A. Delgado Huertas, R. J. Poreda, and S. Kojima (2009a), The magmatic- and hydrothermal-dominated fumarolic system at the Active Crater of Lascar volcano, northern Chile, Bull. Volcanol., 71, 171-183, doi:10.1007/ s00445-008-0216-z.

Tassi, F., B. Capaccioni, F. Capecchiacci, and O. Vaselli (2009b), Nonmethane Volatile Organic Compounds (VOCs) at El Chichón volcano (Chiapas, Mexico): Geochemical features, origin and behavior, Geofis. Int., 48(1), 85-95.

Tassi, F., G. Montegrossi, B. Capaccioni, and O. Vaselli (2010a), Origin and distribution of thiophenes and furans in thermal fluid discharges from active volcanoes and geothermal systems, Int. J. Mol. Sci., 11, 1434-1457, doi:10.3390/ijms11041434.

Tassi, F., F. Aguilera, T. Darrah, O. Vaselli, B. Capaccioni, E. Medina, R. J. Poreda, and A. Delgado Huertas (2010b), Fluid geochemistry of geothermal systems in northern Chile, J. Volcanol. Geotherm. Res., 192, 1-15, doi:10.1016/j.jvolgeores.2010.02.006.

Tassi, F., F. Capecchiacci, A. Buccianti, and O. Vaselli (2012), Sampling and analytical procedures for the determination of VOCs released in air from natural and anthropogenic sources: A comparison between SPME (Solid Phase Micro Extraction) and ST (Solid Trap) methods, Appl. Geochem., 27, 115-123, doi:10.1016/j.apgeochem.2011.09.023.

Tedesco, D., and K. Nagao (1996), Radiogenic ${ }^{4} \mathrm{He},{ }^{21} \mathrm{Ne}$ and ${ }^{40} \mathrm{Ar}$ in fumarolic gases on Vulcano: Implication for the presence of continental crust beneath the island, Earth Planet. Sci. Lett., 144, 517-528, doi:10.1016/ S0012-821X(96)00196-3.

Tedesco, D., G. Miele, Y. Sano, and J. P. Toutain (1995), Helium isotopic ratio in Vulcano Island fumaroles: Temporal variations in shallow level mixing and deep magmatic supply, J. Volcanol. Geotherm. Res., 64, 117-128, doi:10.1016/0377-0273(94)00045-I.

Thompson, K. F. M. (1987), Fractionated aromatic petroleums and the generation of gas condensates, Org. Geochem., 11, 573-590, doi:10.1016/ 0146-6380(87)90011-8.

Tomov, A., F. Fajula, and C. Moreau (2000), Vapour-phase synthesis of thiophene from crotonaldehyde and carbon disulfide over promoted chromia on y-alumina catalysts, Appl. Catal., A, 192, 71-79, doi:10.1016/ S0926-860X(99)00336-1.

Tonarini, S., P. Armienti, M. D’Orazio, and F. Innocenti (2001), Subduction-like fluids in the genesis of Mt. Etna magmas: Evidence from boron isotopes and fluid mobile elements, Earth Planet. Sci. Lett., 192, 471-483, doi:10.1016/S0012-821X(01)00487-3.

Vaselli, O., F. Tassi, G. Montegrossi, B. Capaccioni, and L. Giannini (2006), Sampling and analysis of volcanic gases, Acta Vulcanol., 18, $65-76$.

Wahrenberger, C. (1997), Some aspects of the chemistry of volcanic gases, $\mathrm{PhD}$ thesis, ETH, Zurich, Switzerland.

Wahrenberger, C., T. M. Seward, and V. Dietrich (1998), Halocarbon compounds in high temperature volcanic gases, paper presented at the International Association of Volcanology and Chemistry of the Earth's Interior General Assembly, Capetown, South Africa.

Wahrenberger, C., T. M. Seward, and V. Dietrich (2002), Volatile traceelement transport in high temperature gases from Kudriavy volcano (Iturup, Kurile Islands, Russia), in Water-Rock Interactions, Ore Deposits, and Environmental Geochemistry: A Tribute to David A. Crerar, edited by R. Hellmann and S. A. Wood, pp. 307-327, Geochem. Soc., St. Louis, Mo. 
Welhan, J. A., and J. E. Lupton (1987), Light hydrocarbon gases in Guaymas Basin hydrothermal fluids: Thermogenic versus abiogenic origin, AAPG Bull., 71(2), 215-223.

Whiticar, M. J., and E. Suess (1990), Hydrothermal hydrocarbon gases in the sediments of the King George Basin, Bransfield Strait, Antarctica, Appl. Geochem., 5, 135-147, doi:10.1016/0883-2927(90)90044-6.

Yu, Z. S., J. A. Warner, R. A. Dahlgren, and W. H. Casey (1996), Reactivity of iodide in volcanic soils and non-crystalline soil constituents,
Geochim. Cosmochim. Acta, 60, 4945-4956, doi:10.1016/S0016-7037 (96)00305-5.

Zolotov, M. Y., and B. Fegley (1999), Oxidation state of volcanic gases and the interior of Io, Icarus, 141(1), 40-52, doi:10.1006/icar.1999.6164.

Zolotov, M. Y., and E. L. Shock (2000), A thermodynamic assessment of the potential synthesis of condensed hydrocarbons during cooling and dilution of volcanic gases, J. Geophys. Res., 105(B1), 539-559, doi:10.1029/1999JB900369. 